\title{
THE DISTRIBUTIONAL IMPACT OF FISCAL POLICY IN GEORGIA
}

\section{Cesar Cancho and Elena Bondarenko}

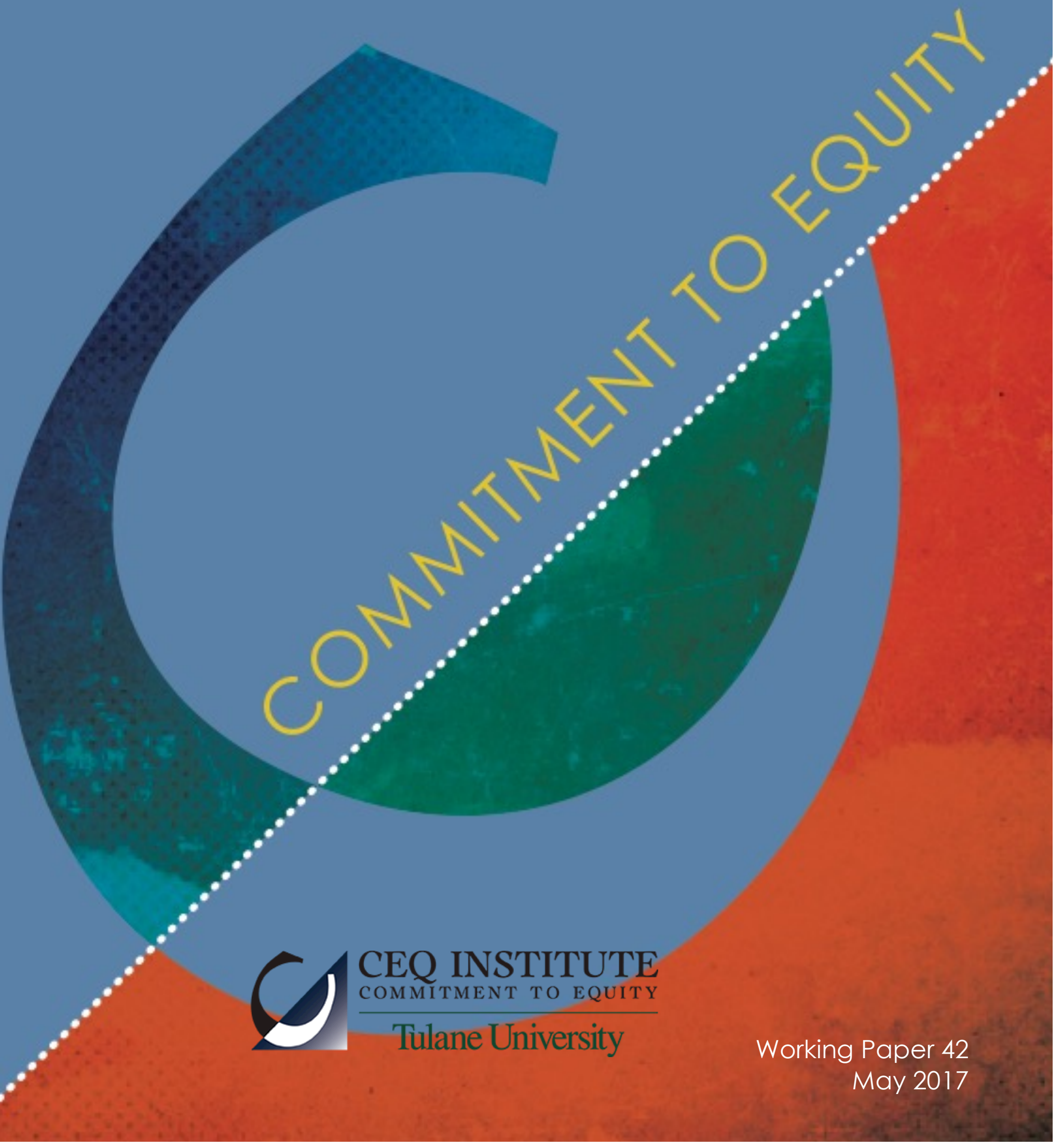




\section{The CEQ Working Paper Series}

The CEQ Institute at Tulane University works to reduce inequality and poverty through rigorous tax and benefit incidence analysis and active engagement with the policy community. The studies published in the CEQ Working Paper series are pre-publication versions of peer-reviewed or scholarly articles, book chapters, and reports produced by the Institute. The papers mainly include empirical studies based on the CEQ methodology and theoretical analysis of the impact of fiscal policy on poverty and inequality. The content of the papers published in this series is entirely the responsibility of the author or authors. Although all the results of empirical studies are reviewed according to the protocol of quality control established by the CEQ Institute, the papers are not subject to a formal arbitration process. The CEQ Working Paper series is possible thanks to the generous support of the Bill \& Melinda Gates Foundation. For more information, visit www.commitmentoequity.org.

The CEQ logo is a stylized graphical representation of a Lorenz curve for a fairly unequal distribution of income (the bottom part

of the $\mathrm{C}$, below the diagonal) and a concentration curve for a very progressive transfer (the top part of the $\mathrm{C}$ ). 


\title{
THE DISTRIBUTIONAL IMPACT OF FISCAL POLICY IN GEORGIA*
}

\author{
Cesar Cancho and Elena Bondarenkot
}

CEQ Working Paper 42

MAY 2017

\begin{abstract}
This paper uses the 2013 Integrated Household Survey, collected by the Central Statistical Agency of Georgia (GeoStat), and data concerning government revenues and expenditures collected by the Ministry of Finance (MoF) along with other administrative agencies, and applies the CEQ methodology to analyze the progressivity of Georgia's tax and transfer systems. The effects of a variety of policies are individually described, including personal income tax (PIT), value added tax (VAT) and excise tax. In addition, this paper assesses direct and in-kind transfers made by the Georgian government. The distributional effect of indirect subsidies, which are confined to the capital city, Tbilisi, are also considered, as well as the Agricultural Card program. The results show a stark difference between direct and indirect taxation. Direct taxes are progressive, and income tax is largely borne by high-income deciles. Meanwhile, the burden of indirect taxation is more evenly distributed, with the poor losing a higher percentage of income. Thus, the tax system is regressive. Overall, fiscal policy is progressive and equalizing, even before in-kind transfers for early education, and the Medical Insurance for the Poor (MIP), and Universal Health Care (UHC) programs are taken into account. The Targeted Social Assistance Program (TSA) and old-age pensions play a significantly pro-poor role. Fiscal incidence reduces poverty (under $\$ 2.50$ USD's per day) over 9 percentage points, the largest drop in poverty amongst the countries where CEQ analysis was performed. This paper concludes that excise taxes should be reassigned or eliminated to reduce regressivity, while PIT and the property tax could be broadened, which would expand the tax base.
\end{abstract}

Keywords: fiscal incidence, taxation, social spending, inequality, poverty, Georgia JEL Codes: H22, D31, I38

\footnotetext{
* This paper was published as a chapter of The Distributional Impact of Fiscal Policy: Evidence from Developing Countries, edited by Gabriela Inchauste and Nora Lustig, World Bank, 2017. This study has been produced by the Commitment to Equity (CEQ) Institute and possible thanks to the generous support from the Bill \& Melinda Gates Foundation. Launched in 2008, the CEQ project is an initiative of the Center for Inter-American Policy and Research (CIPR) and the department of Economics, Tulane University, the Center for Global Development and the Inter-American Dialogue. The CEQ project is housed in the Commitment to Equity Institute at Tulane. For more details visit www.commitmentoequity.org.

${ }^{\dagger}$ Cesar Cancho is an Economist, Poverty \& Equity Global Practice, at the World Bank; Elena Bondarenko is an Economist, Macroeconomics \& Fiscal Management Global Practice, at the World Bank.
} 


\section{Introduction}

Georgia is a small lower-middle-income country with a per capita gross domestic product (GDP) of US \$3,670 (2014) that ranks among the highest in poverty and inequality indicators in the Europe and Central Asia region (figure 1).

The poverty reduction trends have been encouraging since the 2000s. In 2000, 51 percent of the population in Georgia lived on less than US $\$ 2.50$ per person per day. ${ }^{1}$ By 2002 , poverty had fallen to 46 percent but remained around the same level until 2011, when it fell slightly to 45 percent of the population. Since then, poverty has fallen more rapidly, reaching 32 percent in 2014.

In contrast, inequality has persisted. Estimates of inequality have persisted at about 40 Gini points since 2000, up from estimates of around 30 points in the late 1980s. ${ }^{2}$ Since 2000, Gini estimates have oscillated between 39 and 40 points, registering 40 points in 2013 and 2014. The high-inequality indicators over this period are explained in part by the prolonged period of social system restructuring that followed the collapse of the Soviet Union in 1991 and dismantling of the universal social protection it had offered.

Figure 1. Georgia Poverty and Inequality Trends and Regional Country Comparisons

a. Poverty in Georgia, 2000-13 b. Inequality in Georgia, 2000-13

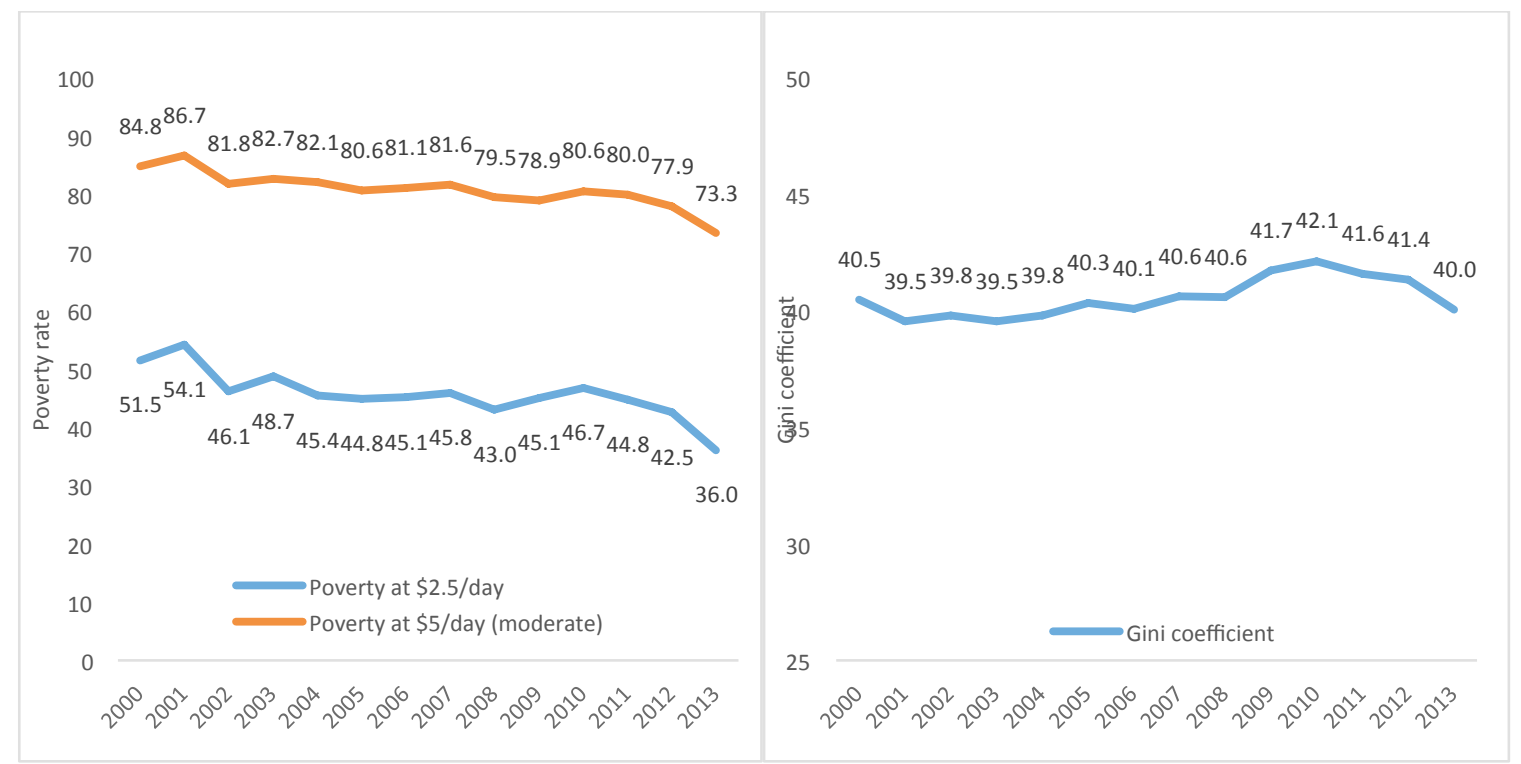

\footnotetext{
${ }^{1}$ As this paper was written, new international poverty lines were reestimated at US\$1.90 and US\$3.10 per person per day, using 2011 purchasing power parity (PPP) exchange rates. This paper uses the previous US $\$ 1.25$ and US $\$ 2.50$ per day poverty lines based on 2005 PPP exchange rates.

${ }^{2}$ Gini index data for Georgia come from the World Income Inequality Database of the United Nations UniversityWorld Institute for Development Economics Research (UNU-WIDER), https://www.wider.unu.edu/data.
} 


\section{c. Poverty in selected countries, Europe and Central Asia ${ }^{\text {b }}$}

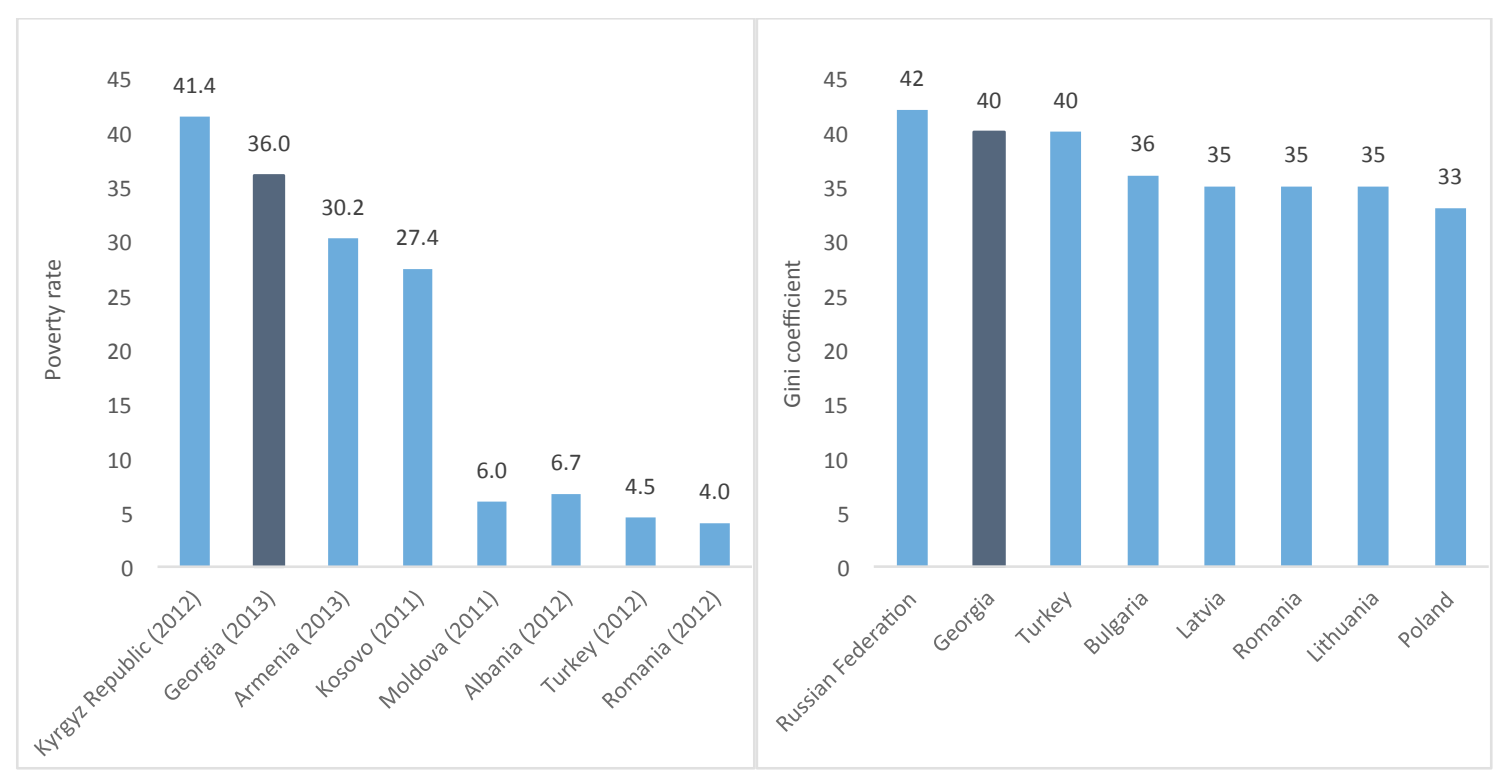

Source: World Bank 2015b.

a. The Gini coefficient indicates the inequality of income distribution, ranging from 0 (full equality) to 100 (maximum inequality).

b. Poverty is defined as US $\$ 2.50$ per person per day at 2005 purchasing power parity (PPP). Country-specific years of data are within parentheses.

After declaring independence from the Soviet Union in 1991, Georgia inherited the Soviet social protection and health system model comprising primarily free health care, a state insurance system, and a pension system. Overall, the system continued to work under its own inertia until 1994, but the expenditures had not met actual needs since 1992, public financing declined, and the order of the system was distorted. The social burden fell almost completely on individuals: social protection programs were limited, pensions were paid irregularly, and individuals were responsible for mandatory health insurance premiums and copayments, which resulted in lower affordability of health services and higher poverty.

The first wave of system changes was characterized by extensive health care reforms during 19952003, followed by deep pro-market reforms and expansion of the social protection system in the mid-2000s. The government started introducing various social transfers; improving pension provision; enhancing health care accessibility for the population living below the poverty line; and extending the coverage, quality, and quantity of social programs (Gzirishvili 2012).

Since 2012, Georgia has been shifting fiscal policy toward greater prioritization of social spending on pension, health, and targeted social programs-expanding these programs to include more beneficiaries and scaling up expenditures as follows: 
- All social transfers were increased, including the universal, noncontributory old-age pensions (the largest social assistance program, covering more than 50 percent of the population). In addition, the Targeted Social Assistance (TSA) allowance, which supports about 10 percent of the population, was doubled. ${ }^{3}$ In fact, previous research has shown that most of Georgia's poverty reduction in 2010-12 is attributable to the expansion of social assistance, with the labor market playing a relatively limited role (World Bank 2014c).

- Health care program eligibility was expanded. From February 2013, all citizens who were not enrolled in the targeted Medical Insurance for the Poor (MIP) program were eligible to enroll in the statefunded, noncontributory Universal Health Care (UHC) program.

- Other expenditure increases included indirect compensation through transfers for small farmers.

On the tax side, the government introduced personal income tax (PIT) refunds for low-wage earners in 2013. The main efforts in tax policy were directed toward sustaining the stability of the tax system. The Economic Liberty Act, adopted in 2011 and entering into force in 2014, introduced the constitutional referendum requirement for new state taxes or increases in existing taxes (except for the excise tax), thus preserving a regulatory policy that helps maintain low pressure on taxation (Government of Georgia 2011).

In this context of expanding social policies, this paper examines how effectively these social transfers and the collected taxes redistribute income from the top to the bottom and lift households out of poverty. In concrete, we seek to answer the following: How much income redistribution and poverty reduction does the government accomplish through taxes, social transfers, and subsidies? How progressive are the government's revenue collection and spending practices? And what are the individual impacts of taxes and transfer policies on inequality and poverty, given the fiscal resources used?

Along those lines, the main contribution of this work is to provide systematic empirical evidence on the progressivity of the fiscal interventions. Although similar studies exist for other countries in the region (for example, Armenia and the Russian Federation), ${ }^{4}$ this study is the first comprehensive examination of Georgia's fiscal instruments and their ability to redistribute income and reduce poverty that - by using a harmonized methodology developed under the Commitment to Equity (CEQ) project (Lustig and Higgins 2013; Lustig, 2018)—allows researchers to produce comparative analytics with other countries in the region and the world. ${ }^{5}$

In the case of Georgia, the main results of this analysis are threefold:

\footnotetext{
${ }^{3}$ Social program data come from the Government of Georgia's Social Service Agency database, http://ssa.gov.ge.

${ }^{4}$ Regarding Armenia, see Younger and Khachatryan (2015). Regarding the Russian Federation, see Lopez-Calva, Lustig, Matytsin and Popova (2017).

${ }^{5}$ Led by Nora Lustig since 2008, the Commitment to Equity (CEQ) project is a joint initiative of the Center for InterAmerican Policy and Research (CIPR); the Department of Economics at Tulane University; and the Inter-American Dialogue. For more details, see http://www.commitmentoequity.org.
} 
- The tax system is regressive overall on account of indirect taxes. Although direct taxes are progressive because their burden falls mostly on formal workers at the top of the income distribution, indirect taxes are more widespread along the distribution and represent a heavier relative burden at the bottom.

- Social spending is reasonably targeted to the bottom of the distribution, effectively acting as a safety net protecting the poor from negative shocks. The TSA program is, by and large, the most progressive social expenditure, and old-age pensions are the most important for poverty reduction.

- Current fiscal policy reduces income inequality and poverty. The joint analysis of taxes and transfers shows that inequality and poverty decrease after all the government interventions are applied, although there is some heterogeneity in the specific impact of different interventions.

The paper is structured as follows: The next section provides an overview of tax and social spending systems that were implemented by the Georgian government in 2013. The "Methodology, Data, and Assumptions" section describes the data and covers the framework and assumptions used for each fiscal intervention in the analysis. The "Main Results" section outlines the redistributive and poverty effects as well as the marginal contributions of individual taxes and transfers. This section also analyzes the progressivity of taxes and social spending by looking at the incidence of each element independently and the impact of all interventions as a whole. "Concluding Remarks" summarizes the paper's findings, noting the current role of government expenditures in reducing poverty and sharing prosperity and proposing policy options to increase the effectiveness of redistribution policies. This section includes recommendations for tax and spending reforms that are in line with fiscal sustainability.

\section{Fiscal Instruments to Tackle Poverty and Inequality}

Georgia generated total revenues of about 28 percent of GDP in 2013, which is below the average overall revenue reported by middle-income countries in the Europe and Central Asia region. Total general government spending in Georgia is also lower than the regional average, amounting to about 29 percent of GDP in 2013. ${ }^{6}$ Tables 1 and 2 in this section show the 2013 breakdown of the major government tax revenue and public spending, respectively, and identify which taxes and transfers were included in the incidence analysis.

\section{Taxes}

Tax revenue represents a significant portion of fiscal revenues in Georgia. ${ }^{7}$ Taxes account for about 25 percent of GDP, with value added taxes (VAT) and PIT being the most important. There are six

\footnotetext{
${ }^{6}$ Average general government revenue in middle-income countries in Europe and Central Asia amounted to 34.9 percent of GDP in 2013 (World Bank 2014b). The average general government expenditure in those countries was 36.6 percent of GDP in 2013.

All information in this section about Georgia's tax structures, exemptions, and rates is taken or paraphrased from the Tax Code of Georgia (Document 3591, issued September 17, 2010), https://matsne.gov.ge/en/document/view/1043717.
} 
taxes in Georgia, of which five (PIT, corporate income tax [CIT], VAT, excise tax, and import tax) are nationwide; one (property tax) is a local tax. There are no capital gains, ${ }^{8}$ inheritance, gift, wealth (except for property), property transfer, social, branch remittance, or other taxes imposed in Georgia.

Based on available data in the household survey, the analysis looks primarily at four major taxes: PIT; property tax; VAT; and excise duties on alcohol, tobacco, and fuel (table 1). Together they make up about 86.2 percent of total general government tax revenues, with the indirect taxes making up almost 54 percent of the total and direct taxes making up a little over 32 percent. The CIT, other nonclassified taxes, and revenues from other sources that are not captured by Georgia's Integrated Household Survey (IHS) are not part of the analysis. Customs duty is omitted because it is not possible to identify whether a purchase was imported; moreover, duties represent only a small share of government revenues.

Table 1. Tax Revenues in Georgia, by Category, 2013

\section{Category}

Total tax revenues

Indirect taxes

Value added tax

Excise taxes

Import taxes

Direct taxes

Personal income tax

Corporate income tax

Property tax

Other taxes

Social security contributions ${ }^{b}$

\section{Share of Share of IA $^{\mathrm{a}}(\%$ of total (\%) GDP (\%) GDP)}

100

10.8

1.3

44.6

29.0

12.1

3.5

0.4
27.7

13.6

10.6

2.7

0.3

11.1

7.2

3.0

0.9

0.1 n.a.

21.4

13.3

10.6

2.7

n.a.

8.1

7.2

n.a.

0.9

${ }^{8}$ Capital gains used in the analysis are tax-exempt; however, some capital gains are subject to tax. For more information, refer to the Tax Code of Georgia (Document 3591, issued September 17, 2010), https://matsne.gov.ge/en/document/view/1043717. 
Source: Based on data from the Ministry of Finance website, http://www.mof.ge/en/.

Note: n.a. = not applicable (not included in the analysis). $-=$ not available.

a. IA = included in the incidence analysis.

b. Georgia does not have a contributory social security system; therefore, data for "social security contributions" are not available.

Georgia relies more on consumption or indirect taxes and less on direct taxes or PIT to finance its public expenditure. Obtaining higher revenue by raising tax rates is restricted; the Economic Liberty Act of 2011 bans the introduction of new state taxes or increases in existing taxes without a nationwide referendum, except for the excise tax. This feature and institutional restriction, along with smaller average revenue than Georgia's peers in Europe and Central Asia, limits the government's ability to affect the distribution of income.

\section{Personal Income Tax}

The PIT structure for 2013, the year of the IHS data, is straightforward in Georgia. Employees pay a flat income tax rate of 20 percent. PIT is levied on individual taxable income, which is the difference between the gross income and deductions during a calendar year. Gross income includes income from employment (salaries, wages, benefits, and other income); income earned from economic activity not related to employment; and income earned from other sources (for example, properties, dividends, and shares).

The PIT system has a number of deductions and exemptions applied in the analysis. Individuals whose taxable income earned as salary does not exceed GEL 6,000 (US\$2,506) ${ }^{9}$ in a calendar year are entitled to a deduction of GEL 1,800 (US\$752) from employment income and can claim a tax refund by filing a tax return with the Georgian tax authorities. Dividends distributed by Georgian companies are subject to a 5 percent withholding tax at the source. Interest payments are subject to a 5 percent withholding tax. Capital gains realized by a resident from the sale of tangible assets are subject to a 20 percent tax.

Certain types of salaries are exempt from income tax: (a) income from the primary supply of agricultural products produced in Georgia if the gross income does not exceed GEL 200,000 (US\$83,530); (b) the first GEL 3,000 (US\$1,253) of income earned by a single mother; and (c) the first GEL 6,000 (US\$2,506) of income earned by a person with a disability. Other tax exemptions are applied to grants, state and private pensions, state compensation, state scholarships, and alimony. ${ }^{10}$ If an income tax payer is eligible to more than one tax privilege (exemption), only the highest privilege is applied.

\footnotetext{
${ }^{9}$ The exchange rate of 1 GEL $=$ US $\$ 0.42$ as of May 10, 2015, is used.

${ }^{10}$ The list includes only the exemptions applied in the analysis. For full list of exemptions, refer to the Tax Code of Georgia (Document 3591, issued September 17, 2010), https://matsne.gov.ge/en/document/view/1043717.
} 


\section{Property Taxes}

Property taxes are levied on taxable property and land, including agricultural, nonagricultural, and forest land. Tax rates are set locally and differentiated according to the income earned by the taxpayer's family. Family income includes taxable income earned from economic activity, any other income (including income not related to economic activity), and gross salary.

A person's taxable property is tax-exempt if the person's gross family income during the year preceding the tax year does not exceed GEL 40,000 (US\$16,706). In addition, property possessed or owned by a person and parcels of land attached to it are exempt from the property tax if such a person cannot use such property because it is being used as a dwelling for internally displaced persons (IDPs) and if the property has been registered as a unit of "compact accommodation" of IDPs.

Real estate tax is applied to the imputed values of properties, unfinished construction, buildings, or their parts. ${ }^{11}$ For families with annual income of GEL 40,000-100,000 (US\$16,706-41,765), the tax rate is $0.05-0.2$ percent of the market value of the taxable property. For families with income equal to or greater than GEL 100,000, the tax rate is $0.8-1$ percent of the market value of the taxable real estate.

Tax rates on agricultural land and forest land used for cultivation (arable, homestead, grassland, and pastureland) are differentiated according to administrative-territorial unit and land category, and are applied to the land size reported in the survey. The tax is calculated in lari per hectare for the regions analyzed in the survey, varying between GEL 13 and GEL 100 (US\$5.40-42.00) per hectare, depending on the region and type of land. Parcels of agricultural land of up to five hectares are exempt from the property tax.

The basic tax rate on land not used for cultivation is GEL 0.24 per square meter of land per year, which is adjusted by the territorial coefficient (up to 1.5) fixed by the local government. However, at the time of this analysis, local territorial coefficients data were not available. This study assumed the basic tax rate for land not used for cultivation.

\section{Value Added Tax}

The standard rate of VAT on domestic sales of goods and services and the importation of goods is 18 percent. In most cases, the amount of VAT is determined based on the transaction price.

Some transactions are exempt from VAT without the right to claim input tax credits. The exemptions relevant for this study include financial services; supply or importation of goods (books, newspapers and magazines, and music); medical services; care services in children's homes; care of

\footnotetext{
${ }^{11}$ The value of property (that is, property subject to real estate tax) is imputed using dwelling and household characteristics reported in the IHS. See the methodology section for more details.
} 
the sick, disabled, and elderly; and public procurement of goods and services related to health care programs or educational services.

In addition, there are a number of exemptions for supply and importation of the following agricultural produce: agricultural produce of Georgia (other than eggs), live plants and vines, fertilizers of animal or vegetable origin, plant or animal products obtained by mixing chemical treatments, agrarian pesticides and agrochemicals, and seed and plant materials of agricultural plants.

\section{Excise Tax}

Georgia applies excise tax to the traditional excisable products (alcohol, tobacco products, means of transport, and various petroleum products) and also on mobile communication service. The tax rates vary by the type of product, as follows:

- Alcohol: Ranging from GEL 2.50 per liter (for wine and champagne) to GEL 4.60 per liter (for liqueurs and cordials)

- Tobacco products: GEL 0.75 per pack (for filtered cigarettes) and GEL 0.20 per pack (for unfiltered cigarettes)

- Oil and fuel products: GEL 0.16 per liter (for fuel and gasoline products), GEL 0.12 per liter (for kerosene and diesel fuel), and GEL 0.33 per cubic meter (for liquefied petroleum gas)

- Mobile communications services: a 10 percent excise tax, introduced in September 2010

\section{Social Spending}

The new government of Georgia that took power in 2012 has shifted fiscal policy toward greater social spending to address poverty and inequality. During the years that followed, the government expanded social programs to include more beneficiaries; increased universal noncontributory pensions and TSA benefits; and, in 2013, introduced universal health care.

Georgia's social protection system is financed entirely out of general revenues and accounts for about 42 percent of total public spending and 12 percent of GDP_one of the highest shares of GDP in the region - with social benefits, especially pensions, being the largest component (table 2). ${ }^{12}$ Most of the poverty reduction seen over 2013-14 is attributable to social assistance, with the labor market playing a relatively limited role (World Bank 2014c).

\footnotetext{
${ }^{12}$ In this analysis, social spending includes social benefits as well as wages, goods and services, subsidies in a form of cash, grants, gross acquisition of nonfinancial assets, and other expenses, per the CEQ methodology.
} 
Table 2. Government Spending in Georgia, by Category, 2013

Percentage of GDP

\begin{tabular}{|c|c|c|}
\hline Category & Total & $\mathbf{I A}^{\mathbf{a}}$ \\
\hline Total government spending ${ }^{\mathrm{b}}$ & 28.8 & 12.0 \\
\hline Primary government spending ${ }^{c}$ & 27.9 & 12.0 \\
\hline Social spending (incl. contributory pensions) ${ }^{\mathrm{d}}$ & 12.1 & 11.0 \\
\hline Social spending (excl. contributory pensions)e & 12.1 & 11.0 \\
\hline Total cash transfers & 6.1 & 6.1 \\
\hline Cash transfers (excl. all pensions) & 1.8 & 1.8 \\
\hline Noncontributory pensions ${ }^{f}$ & 4.3 & 4.3 \\
\hline Total in-kind transfersg & 5.2 & 4.1 \\
\hline Education & 2.8 & 2.5 \\
\hline Tertiary education & 0.3 & 0.3 \\
\hline Health & 1.8 & 1.6 \\
\hline Contributory ${ }^{\mathrm{h}}$ & n.a. & n.a. \\
\hline Noncontributory & 1.8 & 1.6 \\
\hline Other social spending ${ }^{\mathrm{i}}$ & 0.8 & 0.8 \\
\hline Contributory pensions ${ }^{j}$ & n.a. & n.a. \\
\hline Non-social spending & 15.8 & 0.7 \\
\hline Agricultural Cards & 0.7 & 0.7 \\
\hline Indirect subsidies & 0.3 & 0.3 \\
\hline Other subsidies & 1.7 & - \\
\hline Other non-social spendingk & 13.3 & - \\
\hline Debt service & 0.9 & - \\
\hline
\end{tabular}

Source: Ministry of Finance budget data, http://www.mof.ge/en/4539.

Note: Percentages based on gross national income per capita of US $\$ 6,799$ PPP 2011. PPP = purchasing power parity. $=$ not available. n.a. $=$ not applicable.

a. IA = included in the incidence analysis.

b. Total government spending $=$ primary government spending + debt service (interest and amortization).

c. Primary government spending $=$ social spending including contributory pensions + non-social spending. 
d. Social spending (including social contributions) $=$ total cash transfers + total in-kind transfers + other social spending

+ contributory pensions.

e. Social spending (excluding social contributions) $=$ total cash transfers + total in-kind transfers + other social spending.

f. Noncontributory pensions are those to which the pensioner (or employee) makes no contributions. In Georgia, the employer makes all contributions on the pensioner's behalf.

g. Total in-kind transfers include government expenditure on health and education programs.

h. Contributory health spending is not applicable to Georgia, where employees do not make contributions toward health spending.

i. "Other social spending" includes a considerable number of small social assistance programs that were not possible to identify in administrative sources and therefore not included in the analysis using the data from the 2013 Integrated Household Survey (IHS).

j. Georgia does not have a contributory social security system; therefore, data for "social security contributions" are not available.

k. "Other non-social spending" includes spending on general public services, defense, public order and safety, economic affairs, environmental protection, recreation, culture, and religion.

\section{Direct Transfers: Social Assistance}

Direct transfers in Georgia are the highest in the region, accounting for 6.1 percent of GDP (World Bank 2014c, 17). Compared with the largest "spenders" identified in the CEQ analysis-Bolivia, Brazil, Costa Rica, and South Africa-Georgia spends twice as much on direct transfers as a percentage of GDP (Lustig 2015).

\section{Pensions}

Unlike all other countries in the Europe and Central Asia region, Georgia's pension system is financed entirely out of general revenues; the employers' social contribution tax was abolished in 2006. ${ }^{13}$ In particular, Georgia has a noncontributory public pension scheme that provides a flat universal pension to all elderly people at the replacement rate of about 19 percent of the 2013 average wage. This pension is the largest social assistance program by its budget and coverage, accounting for 4.3 percent of GDP and covering 686,675 beneficiaries in 2013, according to Ministry of Labor, Health and Social Affairs of Georgia. ${ }^{14}$

With the coverage to all pensioners, pension payments start at 65 years of age for men and 60 years of age for women. The basic pension was GEL 150 (US\$63) per month in the first eight months of 2013. The level was raised by 2.6 percent, to GEL 154 (US\$64.68), in September 2013.

\footnotetext{
${ }^{13}$ See, for instance, Nutsubidze and Nutsubidze (2015).

${ }^{14}$ All social assistance data in this subsection come from the Social Service Agency of the Ministry of Labor, Health, and Social Affairs of Georgia, http://ssa.gov.ge/index.php?sec_id=610\&lang_id=ENG.
} 


\section{Targeted Social Assistance}

The analysis includes TSA, Georgia's second-largest social assistance program, which aims to reduce poverty and inequality. TSA is a pecuniary social assistance program (subsistence allowance) to provide income support and help with consumption smoothing among the poor households and various vulnerable groups in Georgia. ${ }^{15}$ The program supports about 10 percent of the population (454,000 beneficiaries in 150,607 households) and amounted to 1.7 percent of GDP as of 2013. ${ }^{16}$

The base TSA allowance for the oldest household member was GEL 30 (US\$12.50) per month, and each additional household member received GEL 24 (US\$10) during the first half of 2013. In July 2013, the base benefit rose to GEL 60 (US\$25) per month plus GEL 48 (US\$20) for each additional member. TSA eligibility is defined by a special formula that includes a number of objective and subjective criteria and calculates a score for registered households based on provided information. All households with a score below 57,000 are eligible for TSA.

\section{Other Social Spending}

A variety of other pensions and social packages available to different groups in 2013 were also included in the analysis. Overall, these "other social spending" transfers accounted for 0.8 percent of GDP. Pensions for disabled individuals without other means of support were paid to 122,940 individuals. Loss-of-breadwinner pensions (survivor's pensions) were distributed to 27,080 surviving individuals or family without other means of support. ${ }^{17}$

The government also subsidized temporary disability benefits, designed for employed persons who are temporarily out of work due to sickness (sickness benefits), childbirth (maternity benefits), or other reasons (needy residents benefits). In addition, the analysis included pensions of disabled veterans, participants in a war, and other special (individual) pensions; social (household) assistance for single pensioners and disabled persons; and assistance for IDPs. Other cash transfers included academic scholarships and monetary benefits for Tbilisi residents to cover utility costs during the winter months.

\footnotetext{
${ }^{15}$ Vulnerable groups are identified under the assessment system; no specific group is preselected. The eligibility of applicant households is determined through a proxy means test that uses a complex formula to measure the welfare of a specific household. If the test score is below a certain threshold, the household automatically gets access to benefits.

${ }^{16}$ Beneficiary and share-of-GDP data from the Social Service Agency of the Ministry of Labor, Health, and Social Affairs of Georgia (http://ssa.gov.ge/index.php?lang_id=ENG\&sec_id=35) and the National Statistics Office of Georgia (Geostat) (http://www.geostat.ge/index.php?action=page\&p_id=200\&lang=eng).

${ }^{17}$ Pension beneficiary data from the Social Service Agency of the Ministry of Labor, Health, and Social Affairs of Georgia: http://ssa.gov.ge/index.php?sec_id=610\&lang_id=ENG.
} 


\section{In-Kind Transfers}

\section{Public Education System}

The system of education in Georgia consists of preschool; general education (primary, basic, and secondary); and tertiary and vocational education. ${ }^{18}$ At all levels of education there are two systems: a free, public education system and a private system. The education sector is dominated by public schools and universities but with a growing share of the private sector in higher and vocational education.

In 2013, Georgia's 2,103 public and 283 private general education schools and universities were teaching more than 700,000 students (World Bank 2014b). For the academic year 2012/13, nearly 88 percent of the students were enrolled in public schools at the preschool, general, and higher education levels while the rest were in private schools. Private education prevails in vocational education institutions, with only 40 percent of the vocational students enrolled in public schools. The total public educational budget accounted for 2.8 percent of GDP in $2013 .{ }^{19}$

Preschool education was cofinanced to the extent of 30 percent by parental contributions until September 2013, when contributions were abolished. The annual total cost per student varied widely across preschools in different municipalities. The country average was GEL 744 (US\$310) in 2013. The parental copay was differentiated: most families would pay about GEL 60 (US\$25) per month, property tax payers (with annual income above GEL 40,000, or US\$16,800) paid around GEL 80 (US\$33) per month, and TSA recipients were exempt from the copay. ${ }^{20}$ These rates are for Tbilisi preschools, and other municipalities have similar schemes with slightly lower rates. The total budget for preschool education was 0.25 percent of GDP and was allocated for 91,300 preschool students in 2013.

General education in public schools is free, while universities' tuition is usually merit-based and paid with state grants. Grants are allocated only for students with high scores on national entrance examinations. The grant amount ranges between 30 percent and 100 percent of total tuition. Schools receive direct fund transfers from the Ministry of Education and Science based on the number of students in a given year. These transfers cover salaries, utilities, and routine maintenance costs. More than 70 percent of all higher education students studied in public universities in 2013, and about a

\footnotetext{
18 The educational system descriptions and public statistics are based on World Bank (2014b).

19 Educational budget data are from the Geostat database, National Statistics Office of Georgia (http://www.geostat.ge/index.php?action=0\&lang=eng), and from the Ministry of Education and Science of Georgia (http://www.mes.gov.ge/?lang=eng).

${ }^{20}$ The copay for all payers was abolished, so copayments are not included in the calculation of "net" in-kind transfers for preschool education.
} 
third received state grants to finance education, in part or in full, of which 3 percent received a needbased tuition grant. ${ }^{21}$ The total budget for general and higher education was 2.2 percent of GDP.

The cost of university education is high and difficult to afford for large part of the population. During 2009-13, the annual tuition fee in most public universities was GEL 2,250 (US\$1,350) per year, which is roughly an average tuition in private institutions. As a share of GDP per capita, this represents 37 percent in public institutions, 94 percent in private research universities, and 51 percent in private teaching universities (World Bank 2014a). This level of tuition fees is common to some post-Soviet countries (Azerbaijan, Armenia, and Kazakhstan) but very high relative to countries in Europe and North America as well as other developed countries (Australia, Japan, the Republic of Korea). This puts Georgia among the countries with the highest tuition fees both in public and private tertiary institutions (Salmi and Andguladze 2011; World Bank 2014a). ${ }^{22}$

Public vocational educational institutions include community and vocational colleges that offer preparatory general education programs and vocational education programs and training. Public institutions are financed through a voucher system, and private operators charge tuition fees. Some students are eligible to receive the state voucher and attend private institutions. The eligibility for vouchers is determined by the students' socioeconomic background and educational standing. ${ }^{23}$

\section{Public Health System}

The health care system in 2013 comprised two major programs: the State Health Insurance Program (or Medical Insurance for the Poor, MIP) and Universal Health Care (UHC). Combined, this noncontributory health spending accounted for 1.8 percent of GDP in 2013 (as shown earlier in table 2).

MIP, launched in June 2011, was designed mostly for the poor, aiming to provide medical services free of charge and without limitation by covering the premiums for health insurance provided by private companies. The beneficiaries of MIP included in the analysis and directly identifiable in the survey are socially vulnerable families, ${ }^{24}$ IDPs, teachers and administrative-technical staff of public schools and vocational training centers, all pensioners, children under 6 years of age, students, and military servants. MIP funds outpatient services; laboratorial and instrumental examinations and tests; medical referrals and prescriptions; and inpatient services, including emergency treatment, hospitalization, surgical intervention, and medical facility expenses.

\footnotetext{
${ }^{21}$ A need-based state grant is available for students from minority-language schools, schools in remote areas, students from conflict zones, students who are either orphans or have several siblings, students eligible for social assistance, and so on. The allocation of the need-based grants also has a merit component in it: students with the highest scores receive the grant.

${ }^{22}$ Gross transfers were used in this calculation, but using net transfers does not change the result qualitatively for any educational level.

${ }^{23}$ Only 41 of the approximately 11,000 households interviewed in the survey reported having a member attending vocational education. Because representativeness would be an issue, vocational education was not analyzed independently but only jointly with other educational levels.

24 "Socially vulnerable" families are those that are registered in the "unified database of socially vulnerable families" with a rating score not exceeding 70,000 units.
} 
Following the October 2012 elections, the government announced that all Georgians, refugees, or stateless persons would be eligible for state-funded health care-that is, UHC. At the end of February 2013, the uninsured population was extended a package that included basic primary health care services paid via capitation to primary care providers by the Social Service Agency (SSA) and coverage of emergency or trauma care at hospitals paid via fee-for-service reimbursement by SSA. In July 2013, this package was expanded to include a comprehensive range of services very similar to those covered by the MIP program already available to the poor, pensioners, teachers, and children.

The program coverage varied by type of beneficiary and type of service. Veterans and individuals reaching retirement age received 100 percent coverage for all services. Other individuals received full coverage for the minimum package (regular outpatient services), preventive services, and most tests, while receiving about 70-80 percent coverage for other services (surgeries, emergency, delivery, and specific tests). These packages mostly exclude an outpatient drug component, on which very high out-of-pocket spending was registered. These services were also reimbursed on a fee-for-service basis by SSA according to the claims submitted by providers.

\section{Non-Social Spending: Subsidies and Agricultural Cards}

\section{Subsidies}

This study includes two subsidies administered by Tbilisi, the capital of Georgia, specifically for Tbilisi residents: the Program of Communal Subsidies (PCS) and the Subsidy for Public Transportation. ${ }^{25}$ The PCS subsidizes the cost of utilities for selected households during the winter months, including electric energy, cleaning, and water payments. Households and families registered in the "Socially Unprotected Households Database in Tbilisi" with a rating score of 70,000 or less are eligible for the PCS in January, February, March, November, and December. All other Tbilisi households receive the PCS in January, February, and March. The PCS covered 382,000 households and accounted for about 0.08 percent of GDP in 2013.

Public transportation in Tbilisi is provided either free or subsidized for eligible individuals (pensioners, teachers, IDPs, people with disabilities, and employees of various ministries including defense) while using the city bus transport, underground electric transport (metro), and cable car. This analysis includes subsidies for retired and socially vulnerable individuals, who pay a reduced fare of GEL 0.20. (The general amount of municipal travel fare equals GEL 0.50, thus 60 percent of total cost of transportation is subsidized.) The total number of beneficiaries in these categories in 2013 was 226,596 (retired) and 164,338 (socially vulnerable). The total Subsidy for Public Transportation budget for all categories of eligible individuals accounted for 0.24 percent of GDP.

\footnotetext{
${ }^{25}$ All subsidy beneficiary and cost information comes from Tbilisi City Hall, unpublished data. Share of GDP from World Bank calculations.
} 


\section{Agricultural Cards}

Agricultural development is one of Georgia's strategic, high-priority issues, and adequate development of the sector can contribute to rapid economic growth and significant improvement of living standards. Under the initiative of the Ministry of Agriculture and with the financial support from the Rural and Agricultural Development Fund (launched in 2013), the Small Landowner Farmers Supporting Spring project was designed to stimulate farmers' involvement in production of one-year and perennial crops if farmers use or actually own up to 5 hectares of agricultural land.

In the 2013 Spring Project, 710,479 beneficiaries (farmers) received assistance in the form of Agricultural Cards worth GEL 195,551,811 (US\$82.1 million), which is about 0.73 percent of GDP. Agricultural Cards worth GEL 190,120,332 (US\$79.9 million), amounting to 0.71 percent of GDP, were cashed by the agricultural goods suppliers and service provider companies by the end of 2013, and 207,326 hectares of beneficiary-owned land were plowed within the project. ${ }^{26}$

Agricultural Cards came in four types with various benefit amounts and eligible purchases. The benefit amount depended on the crop type (perennial or one-year crop) and the land area. Eligible purchases included plowing and disking the soil, farming goods, agricultural materials, and equipment. Some of the qualified farmers did not receive the benefits in 2013 because of identification issues. The list of potential beneficiaries was expanded to 800,000 farmers for the Spring Project of $2014 .^{27}$

\section{Methodology, Data, and Assumptions}

\section{Methodology}

Following the recommendations of the CEQ project's state-of-the-art incidence analysis, here we describe the methodology followed to construct the five key income concepts: market income, net market income, disposable income, consumable income, and final income.

We assume that the income reported by each household in the IHS comes from labor, capital, and property incomes net of taxes. We also assume that the burden of taxes falls entirely on the household in the form of lower income or increased prices. Thus, the analysis starts by identifying "net market income" as the aggregation of net labor income, net income from capital, and net income properties and private transfers. From net market income, we construct "market income" by grossing up by the amount paid in direct taxes. Therefore, market income comprises gross (pretax)

\footnotetext{
${ }^{26}$ Spring Project data from "The Land-Poor-Farmers Assistance 2014 Spring Project," Government of Georgia website (accessed May 2, 2016), http://gov.ge/print.php?gg=1\&sec_id=288\&info_id=41117\&lang_id=ENG. Unfortunately, information is unavailable on the average total farming cost for farmers with less than 5 hectares of land, to account for the percentage covered by the Agricultural Card program.

${ }^{27}$ The Ministry of Agriculture and Project Management Agency, with the help of local governments, specified the list of potential beneficiaries.
} 
wages, salaries, income earned from capital assets (rent, interest, profits, or dividends). Pensions are not treated as part of market income. ${ }^{28}$

In addition, we include in market income the value of self-production (also referred as autoconsumption), imputed rent for owner-occupied housing, private transfers (remittances and other private transfers such as alimony), and income from the sale of agricultural production. The value of self-production is calculated based on reported products of own production (or received free of charge) valued at median local market prices. The imputed value of owner-occupied housing is estimated using national accounts information, which estimates this value at 4.4 percent of total household expenditures. Income from the sale of agricultural products is collected in the IHS, and thanks to the survey design (rotating panel) and available data for the previous and following year, we are able to capture sales for the whole year, avoiding seasonality issues. Market income is then divided by the number of members in each household to arrive at per capita market income.

"Disposable income" is constructed by adding direct cash transfers to net market income. These transfers mainly include pensions, assistance for socially vulnerable families (TSA), Agricultural Cards, the monetary benefits for families in need in Tbilisi, and other minor transfers.

Next, we create "consumable income" (also sometimes called postfiscal income) by (a) subtracting from disposable income the impact of indirect taxes (VAT and excise taxes), and (b) adding to disposable income the subsidies distributed by the municipality of Tbilisi for utilities and transportation.

We obtain "final income" by adding to consumable income in-kind benefits-in this case, free or subsidized health and education services. The specific assumptions regarding tax shifting, tax evasion, program take-up, and monetization of in-kind transfers in education and health are presented in the "Assumptions" subsection below.

There are some important caveats about what the fiscal incidence analysis does not address. We are unable to include some important taxes and spending that are included in the general government budget. Revenues such as corporate income and international trade as well as spending categories such as infrastructure investments (including urban services and rural roads, for example) are excluded even though they affect income distribution and poverty. ${ }^{29}$ In addition, since the analysis focuses on tax and spending programs that are on-budget and are part of by the general government, it excludes operations of state-owned enterprises.

\footnotetext{
28 The CEQ framework (Lustig and Higgins 2013; Lustig, 2018) recommends doing the fiscal incidence analysis under two main assumptions for contributory pensions: (a) a "benchmark scenario," under which contributory pensions are assumed to be deferred income and are counted as part of market income; and (b) a "sensitivity analysis," under which contributory pensions are treated as any other direct cash transfer. Because Georgia does not have a contributory pension system, our study treats all pensions as transfers.

${ }^{29}$ The empirical tools necessary to undertake incidence analysis of corporate taxes and investment spending are not well established in the literature and were beyond the scope of what could be done in this study.
} 


\section{Data}

The income concepts are built using the 2013 IHS microdata collected by the National Statistics Office of Georgia (Geostat). The survey is representative at the national level, for urban and rural areas, and at most administrative divisions (all nine regions and one city, Tbilisi). ${ }^{30}$ It contains data on household income, expenditures, cash transfers, utilization of health and educational services, and characteristics of households and their members for 11,102 households and 39,926 individuals.

Data on government revenues and expenditures for 2013 come from the Ministry of Finance (MoF), the MoF's Treasury Service, and the SSA. Data on education enrollments and spending come from the $\mathrm{MoF}$ and the Ministry of Education and Science of Georgia. Aggregate data on other macroeconomic (GDP, population, consumption, and so on), poverty, and inequality variables are obtained from Geostat, the World Bank's World Development Indicators database, and the World Bank's Europe and Central Asia Team for Statistical Development.

Georgia's national accounts and administrative fiscal data are used to map the taxes and transfers to individual members in household. In some instances, as in the case of most transfers, information reported in the IHS matches quite closely with the administrative records. In other instances (for example, income taxes and subsidies), no information is available in the survey, and the household level information is imputed based on usage data, consumption data, or the reported use of public services by individual households. By assigning or using the taxes and transfers reported in the survey, we are able to construct the four different income categories required for the analysis.

\section{Assumptions}

\section{Taxes}

Tax assumptions are as follows. The PIT burden is borne by the income recipient. Personal income taxes are not reported in the IHS; therefore, we simulated them based on the reported earned income, which is assumed to be net of taxes (net market income). In the case of labor income, we assumed a rate of 20 percent withheld by employers, applying tax deductions and exemptions to qualified households in accordance with the Tax Code (low-wage earners, single mothers, and persons with disabilities). Our incidence analysis assumed that individuals receiving income from self-employment or from a secondary job evade taxes. Income earned abroad is not subject to income taxation.

Property taxes on real estate were estimated by applying statutory tax rates to the imputed real estate property value. Property values were imputed using a model for real estate property values—a linear regression on the logarithm of the dwelling price, against characteristics of the dwelling, household income per capita, and location dummies (region and urban/rural). All variables are reported in the

\footnotetext{
${ }^{30}$ Georgia is geographically divided into nine regions, one city, and two autonomous republics. Abkhazia and South Ossetia regions are not covered in the survey.
} 
survey. ${ }^{31}$ Property taxes on land were also estimated by applying tax rates to the land area reported in the survey.

The burden of consumption taxes were assumed to fall entirely on the consumers in the form of increased prices. To take into account informality and ineffective tax administration, effective tax rates were applied to all household purchases excluding exempt goods. ${ }^{32}$ The effective rate of the VAT was calculated as a ratio of total VAT revenue collections in 2013 to the consumption in the national income accounts that was subject to VAT. ${ }^{33}$ The tax was estimated by applying the effective tax rates to household expenditures, excluding the exemptions provided by the Tax Code. Excise rates were also applied to household purchases using effective rates. The effective tax rates were obtained as a ratio of total excise revenue collections to the consumption data. ${ }^{34}$ Excise taxes paid were estimated based on the type and the quantity of the excisable product consumed (as provided in the survey) using effective tax rates.

\section{Transfers}

\section{Direct Transfers}

The direct transfers collected in the IHS are the old-age pension; disability pension; IDP benefits; assistance for socially vulnerable families (TSA); and other, smaller transfers. ${ }^{35}$

In addition, we considered the Agricultural Cards to be a direct transfer. The money received through this program can only be used for agricultural production-related items such as seeds or plowing equipment, so it is not a traditional cash transfer program whereby the recipient can freely spend the money. However, we categorize it as a direct transfer because its definition is closest to that of the other types of transfers and subsidies defined by the CEQ methodology. The

\footnotetext{
${ }^{31}$ Close to 20 percent of observations report a selling price. This information was used to project price to the rest of the sample.

${ }^{32}$ We didn't estimate the indirect effects of VAT due to cascading because our household survey includes a relatively small number of exempt goods. The effective tax rates account for unreported consumption of alcohol and cigarettes. The calculations are based on the data from Ericksen et al. (2015) Geostat (http://www.geostat.ge/index.php?action=0\&lang=eng); $\mathrm{Ng}$ et al. (2014); the MoF's Treasury Service (http://www.mof.ge/en/4513); and WHO (2015).

${ }^{33}$ Effective tax rate calculations included not only the de facto tax revenue but also underreported consumption of alcohol and cigarettes (Ericksen et al. 2015; WHO 2015).

34 The data on per capital alcohol consumption in 2010 come from WHO (2015) and were used with revenue data for 2010 to calculate effective excise tax rates for alcoholic beverages. The data on per capita consumption of cigarettes come from Ericksen et al. (2015) and $\mathrm{Ng}$ et al. (2014). Consumption data on oil, oil products, and telecommunication services come from Geostat: http://www.geostat.ge/index.php?action=0\&lang=eng. Revenue data are from the MoF's Treasury Service: http://www.mof.ge/en/4513.

${ }^{35}$ The other, smaller transfers include the loss-of-breadwinner (survivor's) pensions; scholarship; temporary disability benefits (due to illness or childbirth); pensions of disabled veterans, participants in a war, or pensions of persons equal to them, and other special (Ministry of Internal Affairs, personal) pensions; social (household) assistance for single pensioners and disabled persons; and other income. The number of beneficiaries obtained in the survey aligned with those reported in administrative sources.
} 
beneficiaries were identified using the eligibility rules of the program, and the transfers adjusted proportional to the size of the plot, as stipulated by the program.

The monetary benefits distributed in Tbilisi through the PCS are not reported in the IHS and were assigned to TSA beneficiaries, following the program eligibility criteria. Therefore, the analysis also includes them among the direct transfers.

In contrast with in-kind transfers, direct transfers reported directly in the IHS were not scaled down but were left as reported in the survey because the aggregate information in terms of beneficiaries and distributed amounts matched reasonably well with the administrative records. ${ }^{36}$ Robustness checks indicated that scaling down direct transfers would lead to similar qualitative results, albeit with smaller magnitudes. ${ }^{37}$

\section{In-Kind Transfers}

In-kind education benefits are calculated as the average government spending per student by type of educational institution (preschool, primary, secondary, tertiary, and vocational), defined as ratio of the budget for each type of school and the number of students. The data on government spending is obtained from the MoF and enrollment data from the Ministry of Education and Science of Georgia.

Since parental copayments for preschool were abolished in September 2013, for simplicity we assumed that households benefited from free preschool during the whole year. To identify preschool, general, higher, and vocational education students, we used information from the household roster in the IHS. However, since the survey reports only attendance but not who attended public institutions, we used data available in the 2011 IHS to identify the percentage of students who attend public schools. Using data on tuition payments in 2013 IHS, we assigned the students with the highest tuition payments to private education until the 2011 percentage was matched.

We used an imputation method and insurance values to estimate in-kind health benefits. For the targeted MIP, which covers the cost of health insurance premiums for families in need, we used information from the household roster where insurance is reported at the individual level to identify beneficiaries and assign the national average premium paid by the government to each beneficiary (GEL 150, or US $\$ 63$ per year). In addition, we included people who satisfied the eligibility criteria (for example, children, IDPs, or people with disabilities).

\footnotetext{
${ }^{36}$ For more about the rationale and methodology for scaling up or scaling down certain transfers in the calculation of the income aggregates, see Inchauste and Lustig (2017).

${ }^{37}$ Scaling down the direct transfers reported in the survey (see endnote 36), as done for in-kind transfers, would have led to a smaller change in the Gini coefficient from market income to disposable income (a fall of 8.4 Gini points instead of 11.2), though a roughly similar final income Gini (39.6 against the current 38.3). Qualitative results on the progressivity and regressivity of taxes and transfers would remain the same.
} 
In contrast, UHC, which directly covers health care expenses, we identified beneficiaries using information from the household roster ("Other forms of health insurance") and information on the use of health services in accordance with the rules of the UHC program. ${ }^{38}$ Each beneficiary is assigned the annual average cost (GEL 350, or US\$147) obtained from the Ministry of Labor, Health and Social Affairs, using benefit amounts for inpatient and outpatient services.

Subsidized public transportation in Tbilisi for pensioners and TSA beneficiaries are estimated using the cost of travel on intraurban and local transportation directly identified in the IHS. ${ }^{39}$ The subsidized tariff is equal to 40 percent of the total cost of transportation. The benefits from the CPS program in Tbilisi are imputed using administrative tariffs and eligibility criteria. We use the administrative amounts of subsidized utilities allocated per eligible household per month to calculate the implicit subsidy for TSA beneficiaries and helpless families who applied for assistance to the SSA.

Other considerations included scaling down the in-kind transfers (health and education) and Agricultural Cards. These benefits were scaled down to better match administrative data, using the ratio between households' consumption reported in the IHS and the national accounts. Spatial deflators were used as a robustness check, and the results were consistent with those without the use of deflation.

\section{Main Results}

\section{Redistributive and Poverty Effects}

Table 3 illustrates how fiscal interventions affect different quintiles of the per capita income distribution. The income of the bottom 60 percent increased moving from market income to final income, with the largest increase experienced by the poorest 20 percent. The top 40 percent, in contrast, are net payers. While indirect taxes reduced the incomes of the poor, social spending raised their incomes considerably.

Comparing market income with consumable (postfiscal) income, which accounts for direct and indirect taxes and cash transfers, the bottom 40 percent saw their income almost double their initial market income. After incorporating in-kind transfers, the income of the bottom 40 percent grew even further, with final income more than doubling their initial market income.

\footnotetext{
${ }^{38}$ Outpatient and prevention services were covered between March and June 2013, and outpatient, preventive care, surgeries, and other inpatient care were covered from July 2013. The IHS reports the following expenditures on health care: outpatient treatment for chronic or disabled patients; outpatient treatment for any disease (excluding chronic); and inpatient treatment, maternal and child health, dental services, preventive inspection, therapeutic appliances, and equipment.

${ }^{39}$ Expenses for local and intraurban transportation are reported at the household level in the IHS. The only provider of this service is the municipality.
} 
Table 3. Distributional Impact of Fiscal Policies in Georgia, by Income Quintile, 2013

\begin{tabular}{|c|c|c|c|c|c|c|}
\hline \multirow[b]{2}{*}{ Measurement } & \multicolumn{5}{|c|}{ Quintile } & \multirow[b]{2}{*}{ All } \\
\hline & $\begin{array}{c}1 \\
\text { (poorest) }\end{array}$ & 2 & 3 & 4 & $\begin{array}{c}5 \\
\text { (richest) }\end{array}$ & \\
\hline Population (no.) & 734,738 & 735,268 & 734,902 & 734,754 & 735,416 & $3,675,077$ \\
\hline Market incomea (US\$/day p.c.) & 0.6 & 1.9 & 3.4 & 5.5 & 13.1 & 4.9 \\
\hline Net market incomeb (US\$/day p.c.) & 0.6 & 1.8 & 3.2 & 5.1 & 11.4 & 4.4 \\
\hline Change wrt market income (\%) & -0.4 & -2.1 & -5.5 & -8.8 & -12.8 & -9.8 \\
\hline Disposable incomec (US\$/day p.c.) & 2.1 & 2.9 & 4.0 & 5.8 & 12.0 & 5.4 \\
\hline Change wrt market income $(\%)$ & 267.3 & 54.1 & 19.4 & 4.3 & -8.3 & 9.6 \\
\hline Consumable incomed (US\$/day p.c.) & 1.8 & 2.5 & 3.5 & 5.1 & 10.9 & 4.8 \\
\hline Change wrt market income $(\%)$ & 216.4 & 34.2 & 4.2 & -7.7 & -17.1 & -2.7 \\
\hline Final income (US\$/day p.c.) & 2.2 & 2.8 & 3.8 & 5.4 & 11.1 & 5.1 \\
\hline Change wrt market income $(\%)$ & 276.3 & 51.2 & 13.5 & -2.4 & -15.3 & 3.5 \\
\hline
\end{tabular}

Source: Based on 2013 Integrated Household Survey (IHS) data.

Note: wrt $=$ with relation to. p.c. $=$ per capita. Income was measured as daily per capita income in U.S. dollars, 2005 purchasing power parity (PPP).

a. "Market income" comprises pretax wages, salaries, income earned from capital assets (rent, interest, or dividends), and private transfers.

b. "Net market income" = market income - direct taxes and contributions.

c. "Disposable income" = market income - direct taxes and contributions + cash transfers (including noncontributory pensions).

d. "Consumable income" $=$ disposable income - indirect taxes (value added, import duties, and excises) + indirect subsidies.

e. "Final income" = consumable income + in-kind transfers (such as health care and education expenditure).

The overall fiscal system in Georgia contributes to reducing poverty and improving equity. Georgia's Gini coefficient falls by more than 0.12 points when moving from market income to final income (table 4). Relative to other countries in CEQ sample, Georgia's reduction in inequality was above average. $^{40}$

Poverty rates are also considerably affected by taxes and transfers. Poverty at the US $\$ 2.50$ per day line falls from 39.2 percent to 30 percent when moving from market to consumable income (table

\footnotetext{
${ }^{40}$ For instance, Brazil (2009) and South Africa (2010) observed Gini reductions of 0.14 and 0.175 , respectively, while Ethiopia (2011), Indonesia (2012) and Armenia (2011) registered reductions of 0.024, 0.026, and 0.046, respectively (World Bank 2015a).
} 
4) - the largest reduction in poverty among countries for which CEQ analysis was performed. ${ }^{41}$ Using the regional moderate poverty line in use by the World Bank (US $\$ 5$ per day), poverty remains at almost the same level when moving from market income (67.1 percent) to consumable income (67.6 percent).

Table 4. Impact of Fiscal Policy on Inequality and Poverty in Georgia, by Income Concept, 2013

\begin{tabular}{|c|c|c|c|c|c|}
\hline Indicator & $\begin{array}{l}\text { Market } \\
\text { income }\end{array}$ & $\begin{array}{l}\text { Net market } \\
\text { income }\end{array}$ & $\begin{array}{c}\text { Disposable } \\
\text { income }^{c}\end{array}$ & $\begin{array}{l}\text { Consumable } \\
\text { incomed }^{\mathrm{d}}\end{array}$ & $\begin{array}{c}\text { Final } \\
\text { income }^{e}\end{array}$ \\
\hline \multicolumn{6}{|l|}{ Inequality } \\
\hline Gini coefficient ${ }^{\mathrm{f}}$ & 0.507 & 0.489 & 0.395 & 0.411 & 0.383 \\
\hline Ratio p90/p10g & 18.7 & 16.5 & 6.2 & 7.0 & 5.8 \\
\hline \multicolumn{6}{|l|}{ Poverty headcount $(\text { FGTO })^{\mathrm{h}}$} \\
\hline US\$2.50/day PPP (\%) & 39.2 & 40.7 & 23.3 & 30.0 & n.a. \\
\hline US\$5.00/day PPP (\%) & 67.1 & 70.4 & 61.5 & 67.6 & n.a. \\
\hline \multicolumn{6}{|l|}{ Poverty gap $(F G T 1)^{\mathrm{h}}$} \\
\hline US\$2.50/day PPP & 20.6 & 21.0 & 8.1 & 11.6 & n.a. \\
\hline US\$5.00/day PPP & 37.5 & 39.1 & 25.8 & 31.2 & n.a. \\
\hline \multicolumn{6}{|l|}{ Poverty intensity $(F G T 2)^{\mathrm{h}}$} \\
\hline US\$2.50/day PPP & 14.1 & 14.3 & 4.2 & 6.6 & n.a. \\
\hline US\$5.00/day PPP & 26.3 & 27.1 & 14.4 & 18.6 & n.a. \\
\hline
\end{tabular}

Source: Based on 2013 Integrated Household Survey (IHS) data.

Note: n.a. = not applicable (not included in table estimates; see note " $\mathrm{h}$ " below). PPP $=$ purchasing power parity.

a. "Market income" comprises pretax wages, salaries, income earned from capital assets (rent, interest, or dividends), and private transfers.

b. "Net market income" = market income - direct taxes and contributions.

c. "Disposable income" = market income - direct taxes and contributions + direct cash transfers (including noncontributory pensions).

d. "Consumable income" = disposable income - indirect taxes (value added, import duties, and excises) + indirect subsidies.

e. "Final income" = consumable income + in-kind transfers (such as public health and education expenditure).

f. The Gini coefficient measures the inequality of income distribution, from 0 (full equality) to 1 (maximum inequality).

${ }^{41}$ For most countries, poverty reduction from market to consumable income is only a few percentage points. 
g. Ratio p90/p10 = ratio of 90 th percentile to 10 th percentile.

h. FGT refers to Foster-Greer-Thorbecke indexes, a family of poverty metrics that presents poverty along three dimensions: The "poverty headcount" (FGT0) is the percentage of the population that is poor. The "poverty gap" (FGT1) is the average percentage by which individuals fall below the poverty line. "Poverty intensity" (FGT2), calculated as the poverty gap index squared at the household level, implicitly gives greater weight to those furthest below the poverty line. The FGT indexes are not estimated here under final income because final income adds only the effects of in-kind transfers, which do not affect household spendable income.

An analysis of households' position income distribution under the different income aggregates shows that only the three top deciles and the households with per capita earnings above US $\$ 5$ per day are net payers, registering final incomes lower than their market incomes (figure 2). Similar dynamics in poverty and inequality reduction are observed when using "per adult equivalent" measures of income distribution. The Gini coefficient falls by about 0.10 points when moving from market income to final income (from 0.483 to 0.374 ). The poverty rate (at US $\$ 2.50$ per day) declines from 20.3 percent to 7.7 percent when moving from market income to consumable income (World Bank 2015a).

\section{Figure 2. Income Aggregates as a Percentage of Market Income in Georgia, by Household Income Decile, 2013}

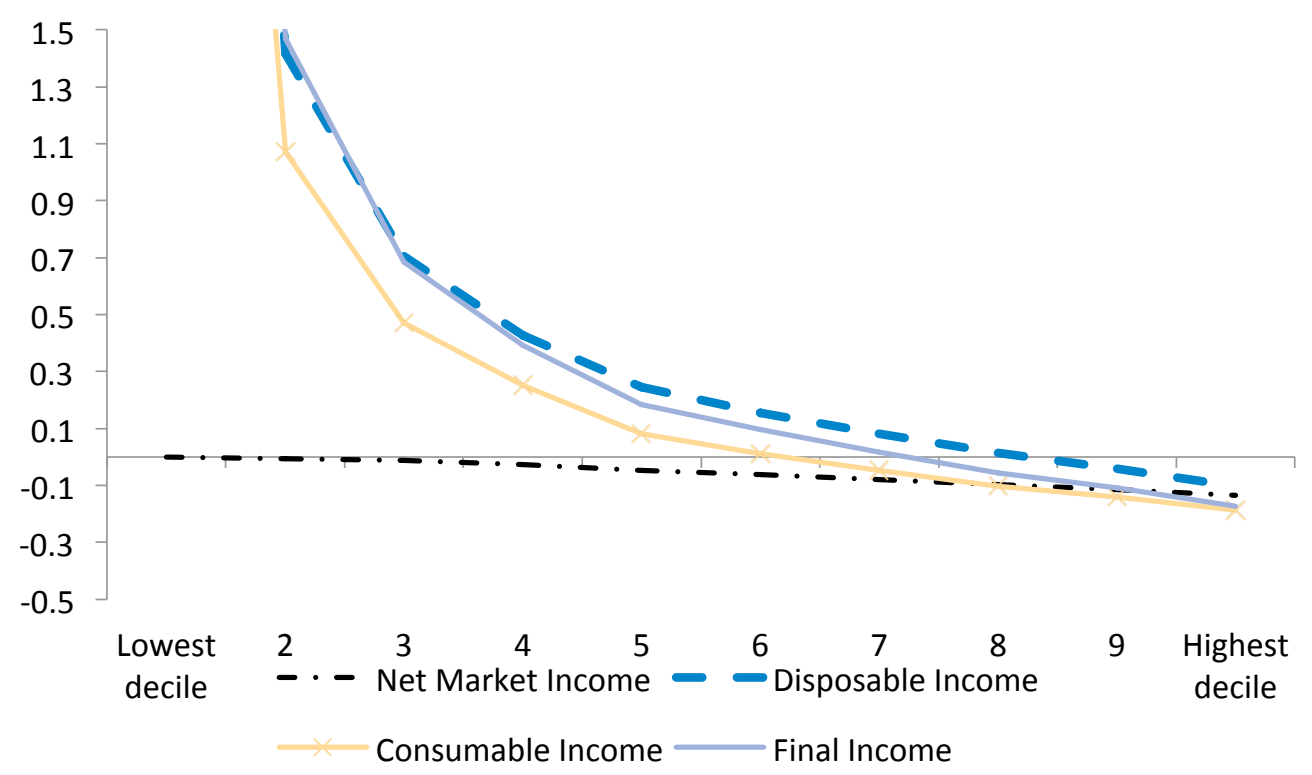

Source: Based on 2013 Integrated Household Survey (IHS) data.

Note: The income aggregates are as follows: "Market income" comprises pretax wages, salaries, income earned from capital assets (rent, interest, or dividends), and private transfers. "Net market income" = market income - direct taxes and contributions. "Disposable income" = market income - direct taxes + cash transfers (including noncontributory pensions). "Consumable income" = disposable income - indirect taxes (value added taxes, import duties and excises) + indirect subsidies. "Final income" = consumable income + in-kind transfers (such as public health and education

The considerable redistribution attained by the fiscal interventions is explained mostly by reductions in vertical equity (VE) rather than by reranking (RR) of the households. (For more about how 
vertical equity, reranking, and horizontal equity are defined and used in the analyses throughout this volume, see Inchauste and Lustig [2017]). RR represents approximately 20 percent, 27 percent, and 21 percent of the VE reduction when moving from market income to disposable income, consumable income, or final income, respectively (table 5).

Table 5. Redistributive, Vertical Equity, and Reranking Effects of Fiscal Policy in Georgia, 2013

\begin{tabular}{|c|c|c|c|}
\hline Indicator & $\begin{array}{c}\text { Disposable } \\
\text { income }^{\mathrm{b}} \text { change } \\
\text { wrt market } \\
\text { income }^{\mathrm{a}}\end{array}$ & $\begin{array}{l}\text { Consumable } \\
\text { income }{ }^{\mathrm{c}} \text { change } \\
\text { wrt market } \\
\text { income }\end{array}$ & $\begin{array}{l}\text { Final income } \\
\text { change wrt } \\
\text { market } \\
\text { income }\end{array}$ \\
\hline Redistributive effect (change in Gini)e & 0.113 & 0.096 & 0.124 \\
\hline Vertical equity $(\mathrm{VE})^{\mathrm{f}}$ & 0.140 & 0.131 & 0.157 \\
\hline Reranking effect $(\mathrm{RR})^{\mathrm{g}}$ & 0.028 & 0.035 & 0.033 \\
\hline Horizontal inequity $(\mathrm{RR} / \mathrm{VE})^{\mathrm{h}}$ & 20.3 & 26.7 & 21.1 \\
\hline
\end{tabular}

Source: Based on 2013 Integrated Household Survey (IHS) data.

Note: wrt $=$ with relation to.

a. "Market income" comprises pretax wages, salaries, income earned from capital assets (rent, interest, or dividends), and private transfers.

b. "Disposable income" = market income - direct taxes and contributions + cash transfers and noncontributory pensions.

c. "Consumable income" = disposable income - indirect taxes (value added taxes, import duties, and excises) + indirect subsidies.

d. "Final income" = consumable income + in-kind transfers (such as public health and education expenditure).

e. "Redistributive effect" refers to the change in inequality associated with fiscal policy (direct and indirect taxes, direct transfers, and subsidies) as shown in the change in the Gini coefficient (a measure of the inequality of income distribution, ranging from 0 for full equality to 1 for maximum inequality).

f. Vertical equity (VE) refers to the change in Gini due to adding different fiscal interventions, while keeping the original ranking fixed. It is equal to the difference between the Gini coefficient for incomes before taxes and transfers and the concentration coefficient for incomes after taxes and transfers.

g. The reranking effect $(\mathrm{RR})$ is a measure of inequity that shows whether the fiscal system changes the ordering of households in the income distribution. It is equal to the difference between the Gini coefficient for incomes after taxes and transfers and the concentration coefficient for incomes after taxes and transfers.

h. Horizontal inequity is calculated as the RR effect as a proportion of the VE effect, or RR/VE.

A complementary measure of fairness of the fiscal interventions, "fiscal impoverishment" (based on Higgins and Lustig 2016), indicates the extent to which households are actually hurt by the interventions - in the case of Georgia, whether the tax and transfer system pushes some nonpoor 
households below the poverty line. Depending on the income aggregates used for this comparison, the percentage of households whose incomes decrease such that they fall below the poverty line (US $\$ 2.50$ per day per capita) is either 2 percent (from market income to disposable income); 13 percent (from market income to consumable income); or close to 7 percent (from market income to final income).

The monetary loss is minimal for those who become fiscally impoverished in the change from market income to disposable income ( 0.2 percent of market income). However, the monetary loss is higher for those who become fiscally impoverished in the other comparisons: it is close to 4 percent from market income and consumable income, and 2 percent from market income to final income.

\section{Progressivity, Marginal Contributions, and Pro-Poorness of Taxes and Transfers}

Overall, Georgia's fiscal system is equity enhancing, although the effects of different taxes and transfers vary in sign and magnitude. Consumable and final income as percentages of market income for different income groups show that the bottom benefits relatively more than the top from these interventions (figure 3). This redistributive effect is driven by the transfers and subsidies in place, although taxes partially offset this effect at the bottom.

\section{Figure 3. Taxes, Transfers, Consumable Income, and Final Income Relative to Market Income in Georgia, by Income Group, 2013}

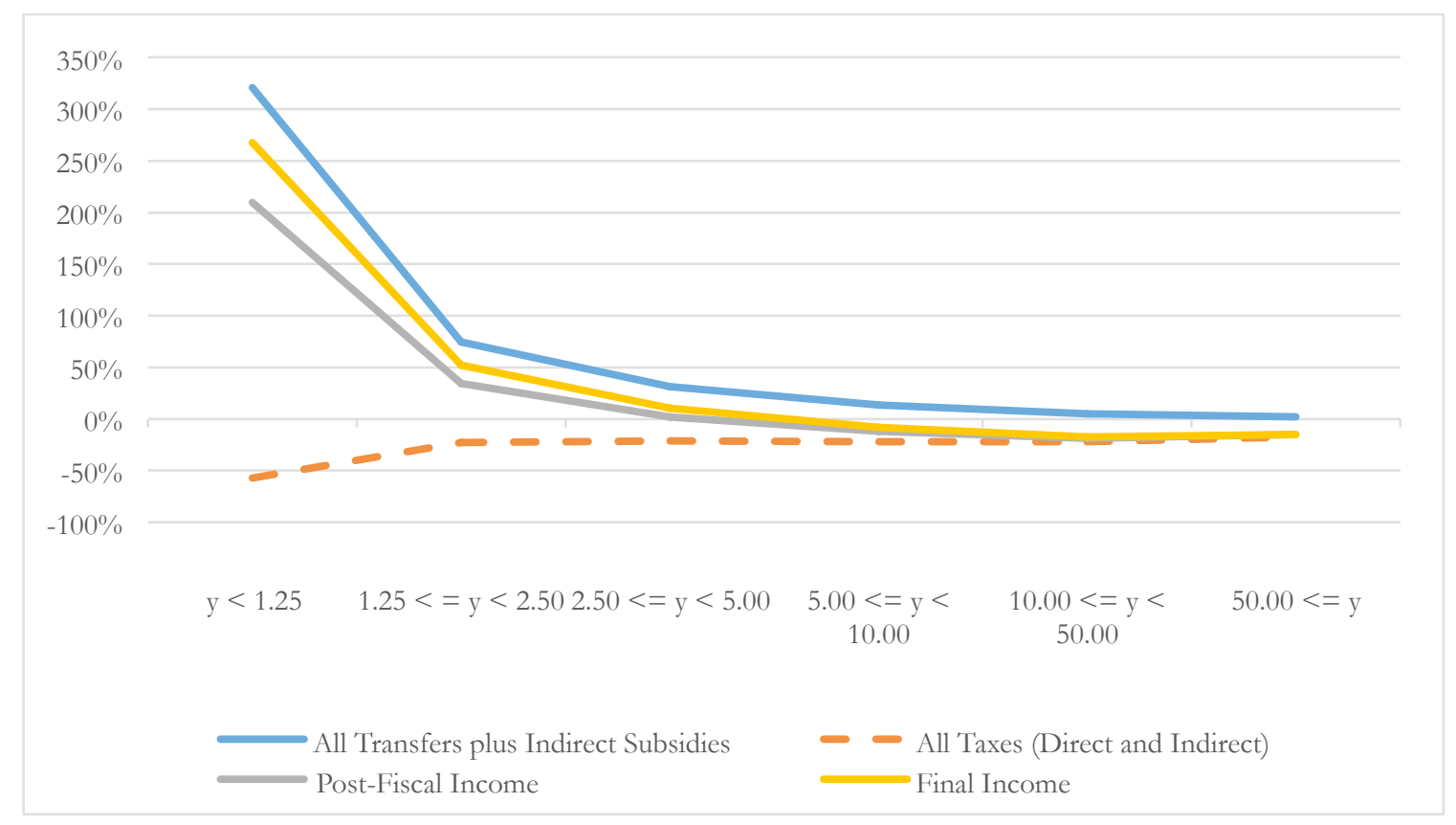

Source: Based on 2013 Integrated Household Survey (IHS) data.

Note: Figure shows curves for transfers, taxes, consumable income, and final income relative to market income, by household income group (y). "Market income" comprises pretax wages, salaries, income earned from capital assets (rent, interest, or dividends), and private transfers. "Consumable income" = market income - direct and indirect taxes + direct cash transfers (including noncontributory pensions) and indirect subsidies. "Final income" $=$ consumable income + in- 
kind transfers (such as public health and education expenditure). "Indirect subsidies" include subsidies for utilities and transportation. "Direct taxes" include income, capital gains, and property taxes. "Indirect taxes" include value added taxes (VAT) and excise taxes.

\section{Taxes}

There is a stark contrast between direct and indirect taxes in their distributional effect: direct taxes are progressive (concentrating more in the top deciles), while indirect taxes are more evenly distributed. Together the result is a regressive tax system, especially for the lowest deciles of the income distribution, while it is almost neutral for the top deciles based on market income. ${ }^{42}$

Georgia's direct tax system is progressive, as shown in the concentration curves for taxes (figure 4). Among direct taxes, PIT is the largest component and is largely progressive despite being a flat-rate $\operatorname{tax}$ (of 20 percent). Other direct taxes are also concentrated in the upper section of the income distribution, hence making direct taxes as a group progressive. In addition, household surveys usually do not capture the top of the income distribution well-where property tax, capital gains tax, and property income tax payments are mostly concentrated-which means that the progressivity of those taxes may be underestimated. Finally, the PIT exemption for low-income earners introduced in 2013 enhanced the progressivity of PIT; without the exemptions, PIT would still be progressive but less so.

\section{Figure 4. Progressivity of Taxes in Georgia, 2013}

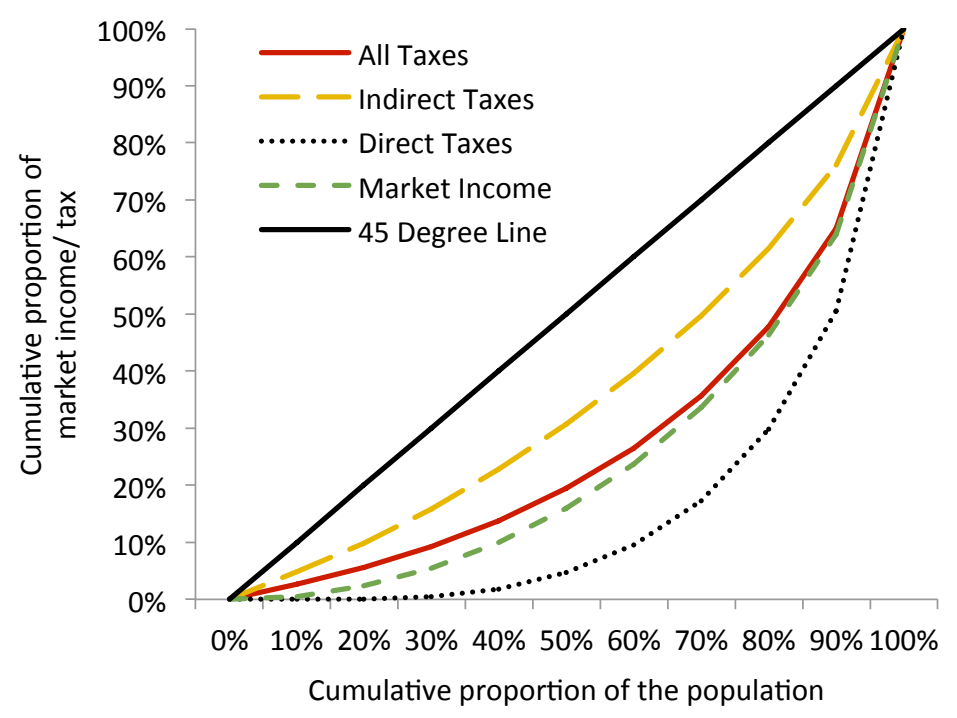

Source: Based on 2013 Integrated Household Survey (IHS) data.

Note: Figure shows concentration curves for taxes and Lorenz curves representing the distribution of "direct taxes," "indirect taxes," "all taxes," and "market income." "Market income" comprises pretax wages, salaries, and income

\footnotetext{
${ }^{42}$ For definitions and methodologies regarding the assessments of progressivity, regressivity, and pro-poorness of the fiscal interventions examined in this volume, see Inchauste and Lustig (2017).
} 
earned from capital assets (rent, interest, or dividends) and private transfers. "Direct taxes" include income, capital gains, and property taxes. "Indirect taxes" include value added and excise taxes.

a. The cumulative proportion of the population is ordered by market income.

In addition, the Kakwani index for direct taxes confirms their progressivity (table 6).

Table 6. Kakwani Indexes for, and Marginal Contributions of, Taxes and Social Expenditures in Georgia, 2013

\begin{tabular}{|c|c|c|c|c|}
\hline & \multirow[b]{2}{*}{$\begin{array}{l}\text { Kakwani } \\
\text { index }^{\mathrm{a}}\end{array}$} & \multicolumn{3}{|c|}{$\begin{array}{c}\text { Marginal contribution, by income concept } \\
\text { (change in Gini index) }\end{array}$} \\
\hline & & $\begin{array}{l}\text { Market to } \\
\text { disposable }\end{array}$ & $\begin{array}{l}\text { Market to } \\
\text { consumable }\end{array}$ & $\begin{array}{l}\text { Market to } \\
\text { final }\end{array}$ \\
\hline $\begin{array}{l}\text { Redistributive effect } \\
\text { (all interventions) }\end{array}$ & n.a. & 0.1125 & 0.0961 & 0.1244 \\
\hline Direct taxes & 0.1818 & 0.020 & 0.021 & 0.022 \\
\hline PIT & 0.1829 & 0.020 & 0.020 & 0.022 \\
\hline Direct transfers & 0.7064 & 0.094 & 0.113 & 0.100 \\
\hline Old-age pensions & 0.6584 & 0.052 & 0.062 & 0.057 \\
\hline TSA & 1.0781 & 0.016 & 0.018 & 0.015 \\
\hline Indirect taxes & -0.2297 & n.a. & -0.018 & -0.014 \\
\hline VAT & -0.2151 & n.a. & -0.014 & -0.010 \\
\hline Excises & -0.3108 & n.a. & -0.006 & -0.005 \\
\hline Indirect subsidies & 0.3715 & n.a. & -0.000 & 0.000 \\
\hline In-kind education & 0.5415 & n.a. & n.a. & 0.020 \\
\hline Preschool & 0.5176 & n.a. & n.a. & 0.002 \\
\hline General & 0.5851 & n.a. & n.a. & 0.016 \\
\hline Higher & 0.2915 & n.a. & n.a. & 0.001 \\
\hline In-kind health & 0.6360 & n.a. & n.a. & -0.008 \\
\hline MIP & 0.7004 & n.a. & n.a. & -0.007 \\
\hline UHC & 0.3717 & n.a. & n.a. & -0.001 \\
\hline
\end{tabular}

Source: Based on 2013 Integrated Household Survey (IHS) data.

Note: n.a. $=$ not applicable. PIT $=$ personal income tax. TSA $=$ Targeted Social Assistance. VAT $=$ value added tax. MIP $=$ Medical Insurance for the Poor. UHC $=$ Universal Health Care. 
a. Kakwani coefficients measure whether a fiscal intervention exercises an equalizing or unequalizing force, calculated by subtracting the intervention's concentration coefficient from the market income Gini; progressive interventions have positive Kakwani coefficients, and regressive ones have negative coefficients.

b. The "marginal contribution" columns show the degree of change in the Gini coefficient from one income concept to another when the designated tax or transfer is taken into account (the Gini being a measurement of income inequality ranging from 0 for full equality to 1 for maximum inequality). The income concepts are as follows: "Market income" comprises pretax wages, salaries, and income earned from capital assets (rent, interest, or dividends) and private transfers. "Disposable income" = market income - direct taxes and contributions + direct cash transfers (including noncontributory pensions). "Consumable income" = disposable income - indirect taxes (value added taxes, import duties, and excises) + indirect subsidies. "Final income" = consumable income + in-kind transfers (such as public health and education expenditure).

Marginal contributions also allow us to conclude that the fiscal system is more equalizing thanks to the progressivity of direct taxes. The marginal contribution of direct taxes to the reduction in the Gini index is close to 0.2 points. Direct taxes increase poverty somewhat, though, increasing the poverty headcount (at per capita income of US $\$ 2.50$ per day) from 40.3 percent to 41.9 percent when direct taxes are subtracted from market income. However, this impact is quite small and largely compensated for by other fiscal interventions.

As for indirect taxes, Georgia's system is regressive. Although the VAT, excise taxes, and indirect taxes overall are more concentrated in the highest deciles, their distribution is less proportional than disposable income, meaning that the poor tend to spend a higher percentage of their income than the rich on indirect taxes. The Kakwani index is negative for indirect taxes (table 6), confirming their regressive nature.

Even though VAT has a number of exemptions, they do not influence the progressivity of the tax. VAT exemptions are distributed across the income distribution in almost the same way as the VAT itself. The exemptions in value terms benefit the upper end of the income distribution the most and, relative to market income, do not quite improve the progressivity of the VAT. Therefore, exemptions, especially the least pro-poor of them, could be eliminated to improve equity and enhance collections. $^{43}$

Georgia's excise taxes are more regressive than the VAT. Excises are the only taxes the government can levy under the Economic Liberty Act without a referendum, but because of their regressive nature, a universal increase of tax rates would make the poor bear a heavier burden.

Overall, the net fiscal system is more unequalizing with the current system of indirect taxes than with direct taxes. The marginal contribution of indirect taxes to the Gini index is estimated at 0.018 if we consider all taxes and transfers except in-kind transfers (consumable income) and 0.0145 when we also include the incidence of in-kind transfers (final income). Indirect taxes also increase poverty,

\footnotetext{
43 This paper does not assess the progressivity of individual VAT exemptions and the consumption share by the poorest decile of population to determine which of the exemptions are the least pro-poor and therefore the best candidates for elimination. However, because a fairly wide range of goods and services are VAT-exempt (from agriculture produce to imported goods and financial services), the impact of VAT exemption is unlikely to be confined to a specific income category.
} 
explaining almost entirely the increase in poverty observed between disposable and consumable income (only marginally affected by indirect subsidies).

\section{Direct Transfers and Indirect Subsidies}

Direct transfers in Georgia are progressive in absolute terms: per capita transfers decline with income, as shown in the concentration curves for transfers (figure 5). The TSA is clearly progressive, concentrating on the bottom deciles of the distribution. Old-age pensions are also progressive in absolute terms and, being the largest program (representing 62 percent of all direct transfers), they influence the final shape of the consolidated Lorenz curve for "all direct transfers."

\section{Figure 5. Progressivity of Selected Direct Transfers and Indirect Subsidies in Georgia, 2013}

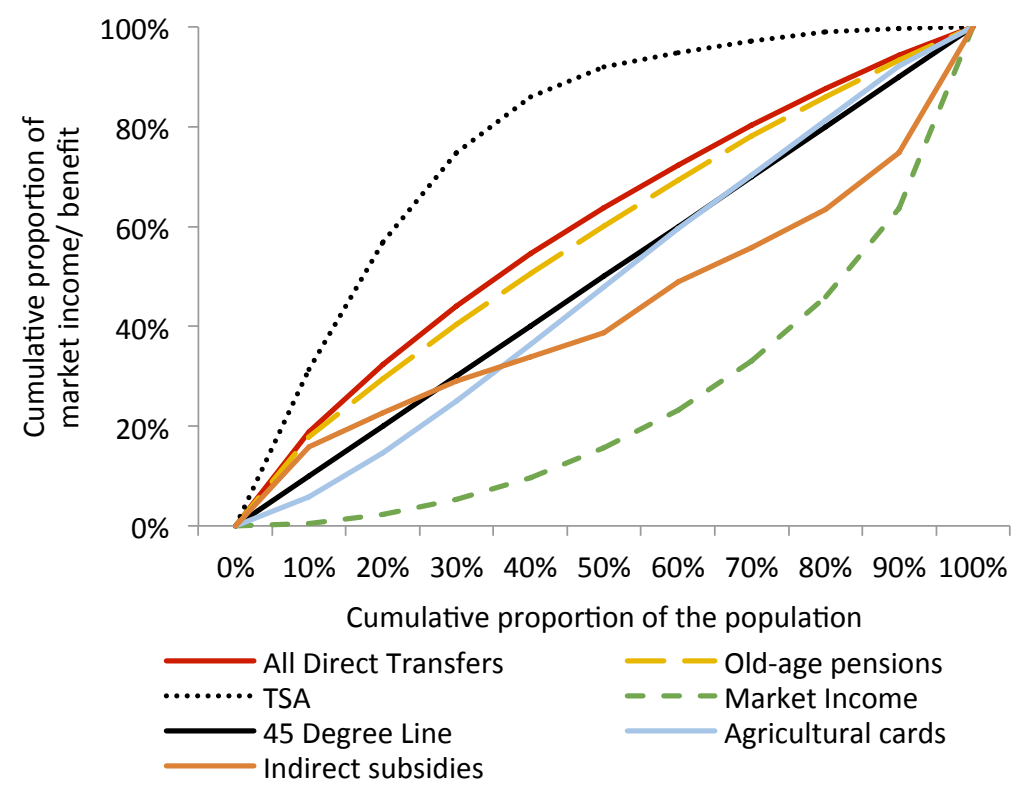

Source: Based on 2013 Integrated Household Survey (IHS) data.

Note: TSA $=$ Targeted Social Assistance. Figure shows concentration curves for spending and Lorenz curves representing the distribution of "all direct transfers" and "market income," which comprises pretax wages, salaries, and income earned from capital assets (rent, interest, or dividends) and private transfers. "Direct transfers" include old-age pensions, TSA, and Agricultural Cards. "Indirect subsidies" include subsidized utilities and public transportation for Tbilisi residents.

a. The cumulative proportion of the population is ordered by market income.

The Agricultural Card program - with a concentration coefficient close to zero (figure 6) and a concentration curve almost equal to the diagonal (figure 5) - is near neutral in absolute terms: that is, the per capita transfer is the same for everybody. ${ }^{44}$ Overall, however, the direct transfers are

\footnotetext{
${ }^{44}$ Small plots are widespread because of state property transfer to households during the reforms of the 1990 s. Tax schemes may also create an incentive to keep plots small. In addition, it is not uncommon for urban household to own plots of cultivable land, which makes them also eligible for the agricultural card.
} 
progressive in absolute terms, and they help to increase considerably the market income of those in the bottom decile in Georgia.

The Kakwani indexes and marginal contributions of cash transfers (as shown earlier in table 6) imply that the progressive nature of cash transfers reduce poverty and inequality in Georgia. Direct transfers are responsible for the large decrease in poverty observed between net market and disposable income (18 percentage points), and they also reduce the Gini index by close to 0.10 points. Pensions, in particular, play an important role in diminishing poverty, given their magnitude. Rough estimations indicate that pensions are responsible for two-thirds of the observed reductions assigned to direct transfers. ${ }^{45}$

The Tbilisi indirect subsidies are progressive in relative terms — as indicated by their Kakwani index (table 6) and by the shape of their concentration curve, which is predominantly below the 45-degree line (figure 5)-but they are not pro-poor. ${ }^{46}$ Although there is some concentration of beneficiaries at the bottom, which drives the curve to go above the 45-degree line for the lowest levels of concentration, most benefits do not go to the bottom of the income distribution. Moreover, these subsidies (the only indirect subsidies considered in this analysis) are only given in Tbilisi, which does not represent the bottom of the national income distribution.

In comparing the values of the concentration coefficients, TSA again is noticeable for the scope of its concentration coefficient, which is much more progressive than that of any other Georgian transfers (figure 6).

\footnotetext{
${ }^{45}$ Similar to the problem encountered with microdecompositions in trying to disentangle the effect of different income components on poverty reduction (see, for instance, Azevedo et al. 2013), contributions of specific programs under this framework cannot rely on sequential calculations because there is path dependency. We could use marginal contributions, but because they do not add up to the total change, one cannot calculate shares of a contribution to the total change. The most proper way to identify this contribution is probably by using some Shapley-style averages. In this case, the estimation is a rough approximation, where pensions are added to net market income first, and poverty reduction is compared with the total reduction and then added after all other components have been added. Because pensions are much larger than the other transfers, we would expect this result to be robust under different specifications.

${ }^{46}$ As further discussed in Inchauste and Lustig (2017), spending is "progressive" when the concentration coefficient is lower than the Gini for market income: that is, the benefits from that spending as a share of market income tend to fall with market income. Spending is defined as "pro-poor" when the concentration coefficient is not only lower than the Gini but also negative. Pro-poor spending implies that the per capita government spending on the transfer tends to fall with market income.
} 
Figure 6. Concentration Coefficients of Social Spending Categories in Georgia, 2013

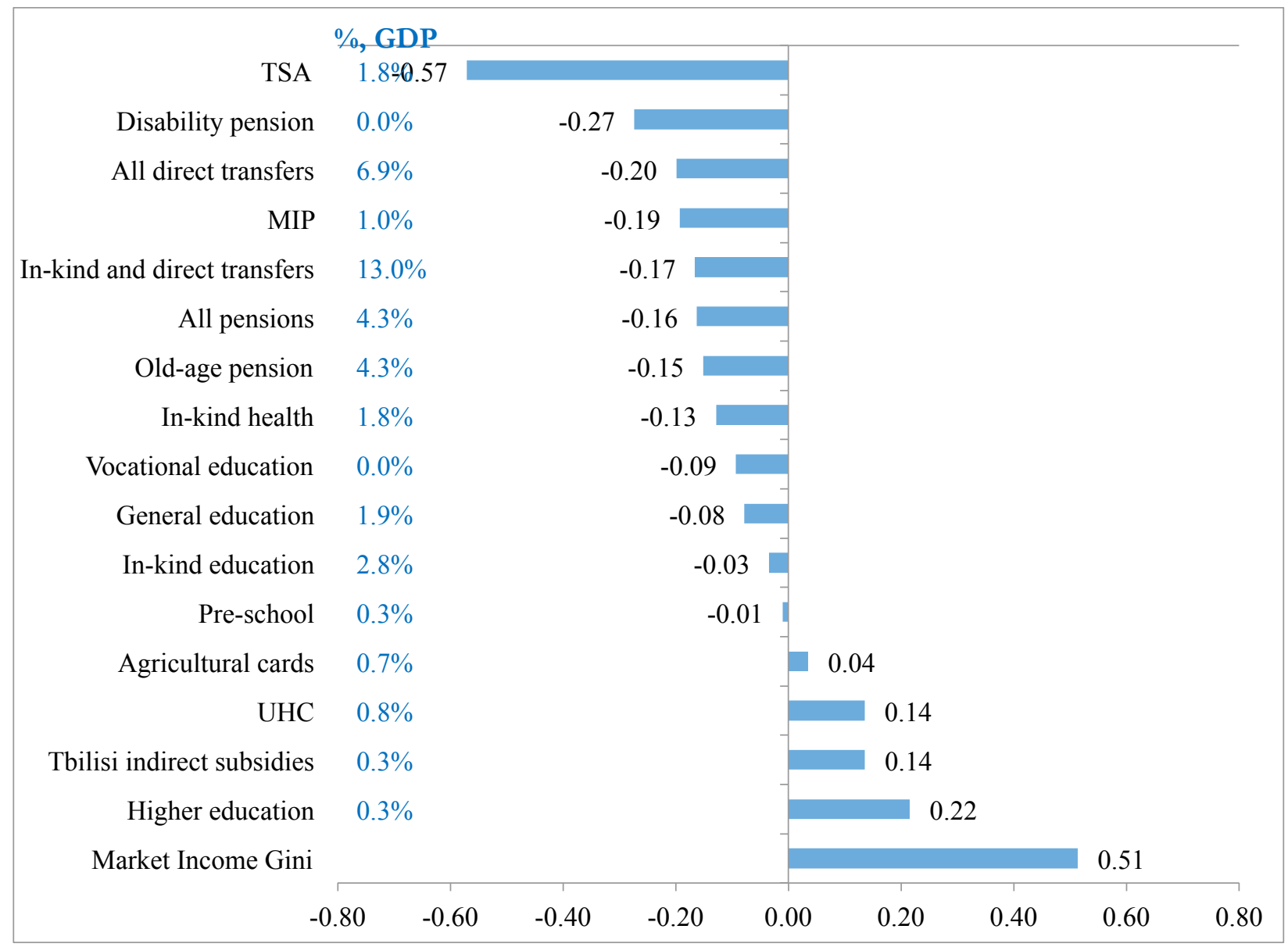

Source: Based on 2013 Integrated Housing Survey (IHS) data.

Note: TSA $=$ Targeted Social Assistance. MIP $=$ Medical Insurance for the Poor. UHC $=$ Universal Health Care. Figure shows the concentration coefficient for each type of social spending relative to its equivalent percentage of GDP (shown in parentheses after each category) when households are ordered by market income (comprising comprises pretax wages, salaries, income earned from capital assets, and private transfers). As further discussed in Inchauste and Lustig (2017), spending is "progressive" when the concentration coefficient is lower than Georgia's market-income Gini (0.51); it is also "pro-poor" when the concentration coefficient is not only lower than the market-income Gini but also negative.

Considering the efficiency of the direct transfers altogether in terms of reducing poverty, they cover a considerable share of the poverty gap (the average percentage by which the poor fall below the poverty line), although many resources go beyond what is necessary to overcome poverty. The poverty reduction efficiency and effectiveness of Georgia's direct transfers, taken together, can be quantified by the following indicators: ${ }^{47}$

- Vertical expenditure efficiency: 54.9 percent of direct transfers go to those identified as marketincome poor (those who are poor before receiving direct transfers).

\footnotetext{
${ }^{47}$ The indicators of poverty reduction efficiency and effectiveness are defined by Beckerman (1979) and Immervoll et al.
} (2009). 
- Poverty reduction efficiency: 34.1 percent of the direct transfers are needed to bring the marketincome poor up to the per capita poverty line of US $\$ 2.50$ per day.

- Spillover: 37.8 percent of the direct transfers benefit the market-income poor after they have reached the poverty line.

- Poverty gap efficiency: 61.3 percent of the direct transfers cover the gap between poor households' incomes and the poverty line.

The vertical expenditure efficiency, roughly 55 percent, signals that although more than half of direct transfers go to the poor, a large share does not. This result is consistent with having old-age pensions (a transfer by design not targeted to the poor) as the main direct transfer and a number of other programs such as the TSA or Tbilisi TSA supplement that effectively benefit the bottom of the distribution.

The poverty reduction efficiency, about 34 percent, shows that roughly a third of the direct transfers go toward moving poor households up to the US\$2.50-per-day poverty line (or at least increasing the incomes of poor households that, after the transfers, remain below the poverty line). Consistent with this result, the spillover of almost 38 percent indicates that more than a third of the resources delivered to the poor through direct transfers are spent moving formerly poor household beyond the poverty line, which can be considered wasteful. Finally, the poverty gap efficiency, roughly 61 percent, shows that direct transfers cover a large portion of the existing gap between poor households' incomes and the poverty line.

\section{In-Kind Transfers}

In-kind transfers - free public services valued at cost, including education and health care-are also progressive as a group, but results for their components differ.

\section{Education}

Education in-kind transfers as a whole are progressive, although the general, preschool, and higher education components have different levels of progressivity.

General education, which comprises the primary and secondary levels, is progressive in absolute terms, reporting a concentration coefficient of -0.08 when households are ordered by market income (as shown in figure 6). Being the largest component of educational expenses (67 percent), it influences strongly the final progressivity of education expenses. Preschool education is also progressive, although it is slightly more concentrated in the upper deciles of the income distribution (figure 7), its concentration coefficient being very close to zero (as shown earlier in figure 6). 


\section{Figure 7. Progressivity of Education Spending in Georgia, 2013}

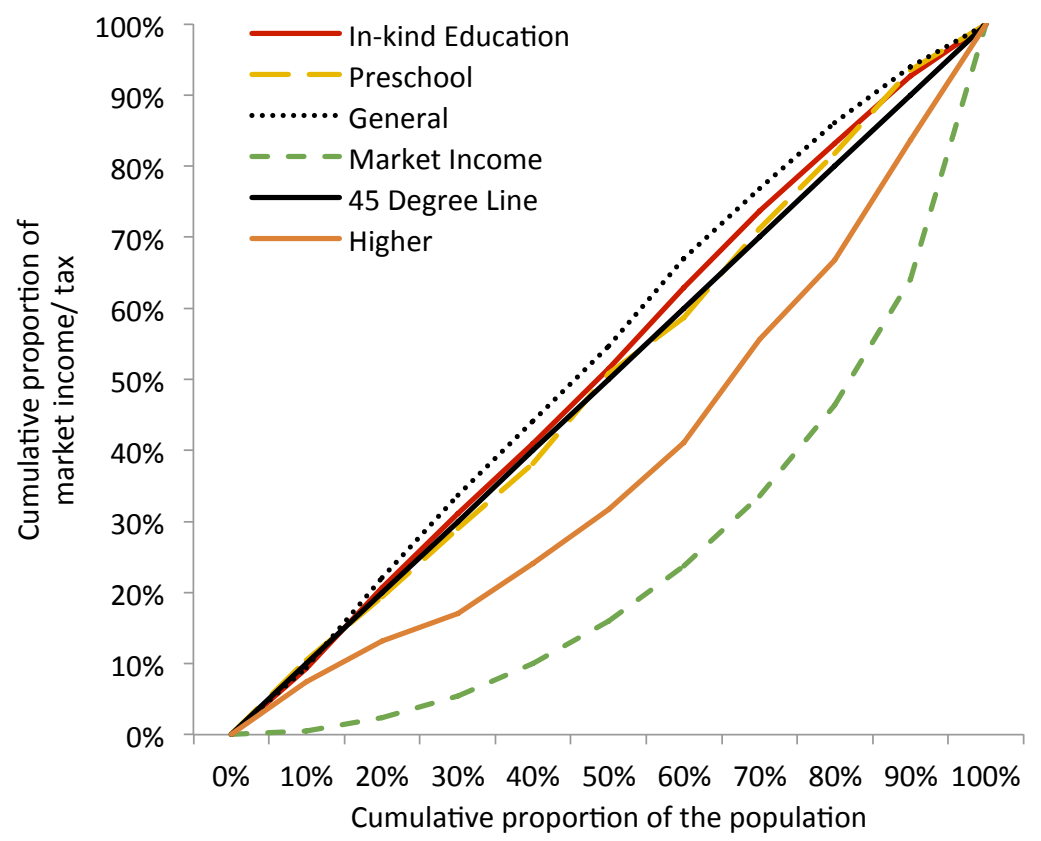

Source: Based on 2013 Integrated Household Survey (IHS) data.

Note: In-kind education benefits are calculated as the average government spending per student by type of educational institution. Data on government spending are obtained from the Ministry of Finance, and enrollment data come from the Ministry of Education and Science of Georgia.

a. The cumulative proportion of the population is ordered by market income.

Finally, the concentration curve for higher education is much closer than the other levels to the curve for market income but is still consistently above it, meaning that although the benefits from higher-education spending are concentrated more heavily among the upper income groups than other educational spending, it is still much less heavily concentrated than market income itself. This last result is consistent with international evidence that higher education is accessible mainly for the middle and upper sections of the income distribution. Representing 10 percent of the budget for education, it contributes toward making educational expenses less progressive, but the effect of general education is predominant. When looking at the marginal contributions, overall education reduces inequality by close to 0.2 points in the Gini index, largely driven by the contribution of general education $(0.16)$.

A public expenditure's coverage rate is the percentage of a qualifying population that benefits from the expenditure. An analysis of the coverage of public education among the households with children of normative age range shows that general education has a very large coverage, reaching close to 90 percent of potential beneficiary households, while preschool and higher education show lower but still considerable coverage rates, at 36 percent and 23 percent, respectively (table 8). ${ }^{48}$

\footnotetext{
${ }^{48}$ Coverage is calculated in relation to the relevant age group, namely ages $1-5,6-17$, and $18-23$ years.
} 
Table 8. Education Coverage in Georgia, by Level and Income Group, 2013

Percentage of potential beneficiary bouseholds

\begin{tabular}{|c|c|c|c|c|c|c|c|}
\hline \multirow[b]{2}{*}{$\begin{array}{l}\text { Educational level by } \\
\text { normative age range }\end{array}$} & \multicolumn{6}{|c|}{ Income group (US\$ per day) } & \multirow{2}{*}{$\begin{array}{c}\text { All } \\
\text { income } \\
\text { groups }\end{array}$} \\
\hline & $<1.25$ & $\begin{array}{c}1.25 \leq y \\
<2.50\end{array}$ & $\begin{array}{c}2.50 \leq y \\
<5.00\end{array}$ & $\begin{array}{l}5 \leq y \\
<10\end{array}$ & $\begin{array}{l}10 \leq y \\
<50\end{array}$ & $\geq 50^{\mathrm{a}}$ & \\
\hline Preschool (ages 1-5) & 33.8 & 32.7 & 39.2 & 38.9 & 31.7 & n.a. & 36.1 \\
\hline $\begin{array}{l}\text { General (primary and } \\
\text { secondary) (ages 6-17) }\end{array}$ & 91.4 & 89.4 & 92.2 & 88.8 & 79.6 & n.a. & 89.8 \\
\hline Tertiary (ages 18-23) & 18.0 & 12.4 & 22.5 & 29.1 & 33.1 & 0.0 & 22.6 \\
\hline Total households & 2.5 & 7.1 & 20.9 & 31.8 & 36.7 & 1.1 & 100.0 \\
\hline
\end{tabular}

Source: Based on 2013 Integrated Household Survey (IHS) data.

Note: n.a. = not applicable (see note "a"). "Education coverage" refers to the percentage of a qualifying group benefiting from public education expenditure. For example, among households living on per capita income of less than US\$1.25 per day, 33.8 percent of children aged 1-5 years receive government-funded preschool education

a. The survey captured very few households in this income group, and among those households, no children of preschool or general-education age are reported.

The distribution of the coverage by income group shows a more nuanced story. In the case of general education, the highest coverage rates are reached at the lowest income level (less than US $\$ 1.25$ per day in per capita income). In contrast, for preschool and higher education, the highest rates are reported in the middle and higher brackets, respectively, although the levels of coverage for the lowest bracket are always significant: about 34 percent for preschool and 18 percent for higher education. These patterns reflect (a) that the government is reaching the bottom of the distribution, although there is still considerable room for improvement; and (b) that programs designed to be universal (such as educational programs) will inevitably devote resources to nonpoor households, as is evident by the coverage rates of the upper income brackets.

\section{Health Care}

Health in-kind transfers are progressive in absolute terms, but different components show different degrees of progressivity. The targeted Medical Insurance for the Poor (MIP) program is progressive in absolute terms-not surprising in that it covers mainly TSA beneficiaries. Universal Health Care (UHC), introduced in mid-2013 to provide medical coverage to large population segments that had lacked health insurance, is more concentrated in the upper deciles of the distribution, albeit to a lesser degree than market income.

A consolidation of all of these programs results in a progressive concentration curve, largely driven by the effect of the MIP (figure 8). The curve for the consolidated health care program is located between the two individual ones, gaining progressivity compared with the original UHC because it 
incorporates both TSA and MIP beneficiaries. The Kakwani indexes also show that Georgia's inkind transfers in health are progressive. And their marginal contribution results show that in-kind health transfers reduce inequality (by 0.008 Gini points), largely driven by the effect of MIP (0.007 Gini points).

Figure 8. Concentration Curves for MIP, UHC, and Consolidated UHC

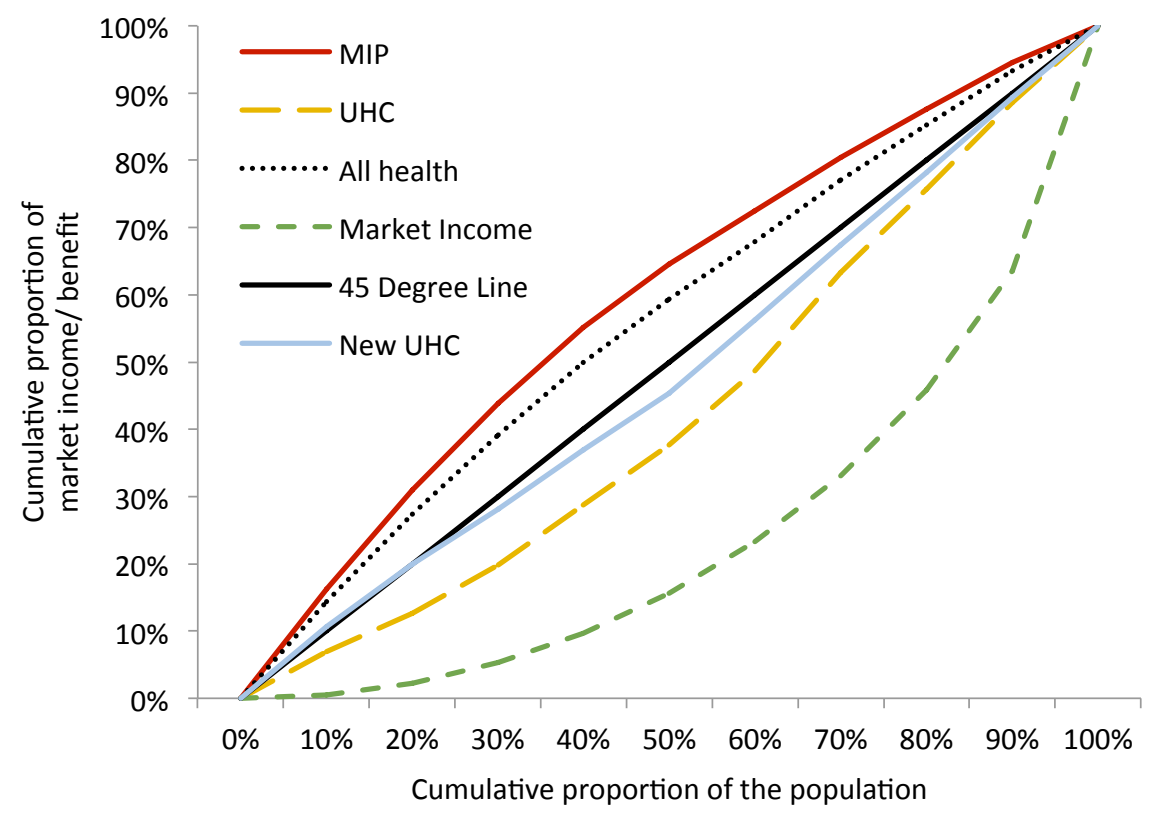

Source: Based on 2013 Integrated Household Survey (IHS) data.

Note: MIP = Medical Insurance for the Poor. UHC $=$ Universal Health Care. "New UHC" refers to a simulated UHC covering all qualifying beneficiaries in the country, including those currently covered by the MIP.

a. The cumulative proportion of the population is ordered by market income.

\section{Concluding Remarks}

This paper analyzed the progressivity of tax and transfer systems in Georgia using the 2013 Integrated Household Survey (IHS) and administrative data, applying the CEQ methodology (Lustig and Higgins 2013; Lustig, 2018). A wide range of fiscal activities were analyzed, among them taxes (personal income, property, value added, and excise taxes); direct transfers (pensions and social assistance programs); in-kind transfers (preschool, general, and tertiary education, universal health care, and targeted medical insurance); the Agricultural Card program; and Tbilisi city benefits and subsidies.

Results indicate that Georgia's social spending system is progressive overall, while its tax system is regressive overall. In addition, the transfers system is effective at decreasing income inequality and poverty, although the reduction is partially offset by indirect taxes. Government programs vary in their impact on poverty and inequality. TSA is one of the programs that best targets the poorest, and 
pensions play an important role in reducing poverty in spite of not being the most efficient program in doing so. Pensions are responsible for two-thirds of the observed poverty reduction due to direct transfers.

The analysis suggests that although the fiscal system is progressive, the tax system can be improved further toward more equity. Specific actions concerning indirect taxation could include refocusing VAT exemptions on basic goods heavily consumed by the poor or limiting the imposition of new excise taxes. The excise tax was the only flexible instrument left after the Economic Liberty Act restricted raising rates on other taxes, but the analysis shows that it is quite regressive. The government has been using excises, but in the future it could consider using them only to levy taxes on items not heavily consumed by the poor. For the VAT, it is advised from an equity standpoint that exemptions that are not pro-poor could be eliminated to improve its progressivity.

Actions concerning direct taxation could include enhancing the property tax by lowering the payment threshold and intensifying PIT collection efforts to broaden the tax base, especially among the better-off households. From an equity perspective, giving direct taxes a bigger role will make the tax system even more progressive. ${ }^{49}$ Although the Economic Liberty Act rules out the possibility of raising either PIT or property tax rates without referendum, there is still space to enhance both.

Finally, regarding in-kind transfers (and in line with the government's intention of creating fiscal space without a drag on growth), the government could introduce a mechanism that encourages the most affluent sectors of the society to use private services, which can reduce the burden on public budget that these programs represent (for example, private health insurance).

\footnotetext{
${ }^{49}$ This paper does not address tax efficiency, and the measures introduced could lead to changes in efficiency.
} 


\section{References}

Azevedo, J. P., G. Inchauste, and V. Sanfelice. 2013. "Decomposing the Recent Inequality Decline in Latin America.” Policy Research Working Paper 6715. World Bank, Washington, DC.

Beckerman, W. 1979. “The Impact of Income Maintenance Payments on Poverty in Britain, 1975.” Economic Journal 89 (354):261-79.

Ericksen, M., J. Mackay, N. Schluger, F. I. Gomeshtapeh, and J. Drope. 2015. The Tobacco Atlas, 5th ed. Atlanta: American Cancer Society.

Government of Georgia, Georgia Adopts the Economic Liberty Act, Press release, (July 11, 2011).

Gzirishvili, David. 2012. Independent Georgia - Health and Social Protection Systems. Analytical Review. Tbilisi: Open Society Georgia Foundation (OSGF).

Higgins, Sean, and Nora Lustig. 2016. "Can a Poverty-reducing and Progressive Tax and Transfer System Hurt the Poor?" Journal of Development Economics 122 (September):63-75. doi: 10.1016/j.jdeveco.2016.04.001.

Immervoll, H., H. Levy, J. R. Nogueira, C. O’Donoghue, and R. Bezerra de Siqueira. 2009. “The Impact of Brazil's Tax-Benefit System on Inequality and Poverty.” In Poverty, Inequality, and Policy in Latin America, edited by S. Klasen and F. Nowak-Lehmann, 271-302. Cambridge, MA: MIT Press.

Inchauste, Gabriela and Nora Lustig. 2017. "Overview: Fiscal Policy and Redistribution." In The Distributional Impact of Fiscal Policy: Experience from Developing Countries, edited by Gabriela Inchauste and Nora Lustig. Washignton DC: World Bank.

Lopez-Calva, Luis Felipe, Nora Lustig, Mikhail Matytsin, and Daria Popova. Forthcoming. "Who Benefits from Fiscal Redistribution in the Russian Federation?" In The Distributional Impact of Fiscal Policy: Experience from Developing Countries, edited by Gabriela Inchauste and Nora Lustig. Washington, DC: World Bank.

Lustig, Nora. 2015. "Inequality and Fiscal Redistribution in Middle Income Countries: Brazil, Chile, Colombia, Indonesia, Mexico, Peru and South Africa. Evidence from the Commitment to Equity Project (CEQ)." CEQ Working Paper 31. CEQ Institute, Tulane University, October.

—, ed. 2018. Commitment to Equity Handbook. Estimating the Impact of Fiscal Policy on Inequality and Poverty. (Brookings Institution Press and CEQ Institute, Tulane University). Advance online version available at http://www.commitmentoequity.org/publications/handbook.php.

Lustig, Nora, and Sean Higgins. 2013. "Commitment to Equity Assessment (CEQ): Estimating the Incidence of Social Spending, Subsidies and Taxes. Handbook." CEQ Working Paper 1. 
Center for Inter-American Policy and Research and Department of Economics, Tulane University and Inter-American Dialogue, September.

National Statistics Office of Georgia, Integrated Household Survey, Analytical report, (Tblisi, 2013).

Ng, M., M. Freeman, T. Fleming, M. Robinson, L. Dwyer-Lindgren, B. Thomson, et al. 2014. "Smoking Prevalence and Cigarette Consumption in 187 Countries, 1980-2012." JAMA 311 (2):183-92.

Nutsubidze, T., and K. Nutsubidze. 2015. "The Challenge of Pension Reform in Georgia: NonContributory Pensions and Elderly Poverty." Working Paper 2015-18. Center for Retirement Research, Boston College.

Salmi, Jamil, and Natia Andguladze. 2011. "Tertiary Education Governance and Financing in Georgia.” Draft policy report. World Bank, Tbilisi.

WHO (World Health Organization). 2015. "Regional Alcohol Per Capita (15+) Consumption by WHO Region.” Global Health Observatory (GHO) Data Repository. WHO, Geneva. http://apps.who.int/gho/data/view.main.52325.

World Bank. 2014a. "Georgia Education Sector Policy Review: Strategic Issues and Reform Agenda." Report No. ACS11059, Georgia: Technical Assistance to Support Preparation of Education Sector Strategy. World Bank, Washington, DC.

- 2014b. "Georgia Public Expenditure Review: Strategic Issues and Reform Agenda.” Report No. 78143-GE, Vol. 1. World Bank, Washington, DC.

—. 2014c. "Georgia: Winds of Optimism.” Georgia Economic Report No. 6, Working Paper 91697. World Bank, Washington, DC.

—. 2015a. "Georgia Public Expenditure Review: Selected Fiscal Issues.” Report No. 96524. World Bank, Washington, DC.

—.2015b. World Development Indicators 2015. Washington, DC: World Bank.

Younger, S., and A. Khachatryan. 2015. "Fiscal Incidence in Armenia." Background paper for forthcoming Armenia Public Expenditure Review. World Bank, Washington, DC. 